\title{
23. SPATIAL AND TEMPORAL VARIATION OF PERUVIAN COASTAL UPWELLING DURING THE LATEST QUATERNARY ${ }^{1}$
}

\author{
Hans Schrader ${ }^{2}$ and Ragnhild Sorknes ${ }^{2}$
}

\begin{abstract}
Two shelf and upper-slope sites (681 and 686) near present cores of active coastal upwelling on the Peruvian margin were sampled continuously at $7.5 \mathrm{~cm}$ intervals down to approximately 25 meters below the seafloor (mbsf). Sedimentary structures were subdivided into homogeneous/bioturbated, laminated, and laminated-varved intervals. Diatom analysis and statistical treatment of data revealed almost persistent upwelling over the last $400,000 \mathrm{yr}$, with slightly increased upwelling during oxygen-isotope Stages 3, 5, 7, and 8 that resulted in anoxic bottom-water conditions and deposition of laminated/undisturbed primary sedimentary structures.
\end{abstract}

\section{INTRODUCTION}

A main objective of drilling along the Peruvian continental margin during Ocean Drilling Program Leg 112 was to retrieve expanded sections of marine sediments that were formed under the influence of strong coastal upwelling conditions and to study the variability of the coastal upwelling phenomena in space and time during the Quaternary and parts of the Cenozoic. This study deals with selected Quaternary intervals of two sites that were retrieved by using the advanced piston (APC) coring system near or within today's most active upwelling centers at $9^{\circ}, 11^{\circ}$, and $14^{\circ} \mathrm{S}$ latitude. Previous studies were limited in the recovery of long undisturbed sediment sections.

Diatoms are by far the most common primary producers inhabiting oceanic and coastal upwelling areas, which are characterized by frequent changes of nutrient content, temperature, salinity, and density. Organisms inhabiting these areas must (1) have large ecological tolerances, (2) be present in a seed pool, and (3) be able to adjust quickly to environmental changes and take advantage of favorable conditions quickly. Diatoms have adapted to these conditions and are successfully competing with other primary producers, such as coccoliths, dinoflagellates, and naked flagellates (Richert, 1975 , 1976). Accordingly, diatoms are the most abundant phytoplankton group inhabiting coastal upwelling-influenced surface waters off Peru (De Mendiola, 1980; Semina, 1971, Sukhanova et al., 1978), and they are found abundantly in hemipelagic sediments east of the Peru Chile Trench.

Diatoms leave an excellent sediment signal of productivity change through time (Diester-Haass, 1978) if their record is unaltered in underlying sediments (Baumgartner et al., 1985). Each diatom cell produces two opaline valves that settle to the seafloor after death of the algae via marine snow, fecal pellets, or density currents. When diatom export production is high enough, dissolution at the sediment/water interface and within the top portions of the sedimentary column should alter the original diatom export signal to only a minor extent (Schrader and Schuette, 1981). Thus, the diagenetic alteration of this primary signal should not undergo as much alteration as would

\footnotetext{
${ }^{1}$ Suess, E., von Huene, R., et al., 1990. Proc. ODP, Sci. Results, 112: College Station, TX (Ocean Drilling Program).

${ }^{2}$ Geological Institute Avd. B, University of Bergen, Allegaten 41, N-5007 Bergen, Norway.
}

other tracers of upwelling, such as chemical tracers, organic carbon, carbonate content, etc.

Schuette and Schrader (1979a, 1979b, 1981a, 1981b) successfully related sediment-surface diatom assemblages to annually averaged primary productivity in surface waters in Peruvian and Namibian continental margin settings. These areas are today's two major areas of extremely high coastal upwelling in the world oceans. These authors defined several assemblages that could be used as productivity tracers. Schrader (in Suess, von Huene, et al., 1988) proposed several diatom and silicoflagellate assemblages that were characteristic of various degrees of upwelling and nonupwelling conditions off Peru.

We encountered similar assemblages in our downcore study and here we address the following: Spatial and temporal distribution of coastal upwelling along the Peruvian continental margin (spanning $2.5^{\circ}$ of latitude) during the last $400,000 \mathrm{yr}$.

\section{MATERIAL AND METHODS}

Samples from two sites (Holes 681A, and 686A, Table 1, Figs. 1 and 2) were used for this study. Both sampling intervals came from their respective lithologic Units I (Suess, von Huene, et al., 1988):

Hole 681A: Lithologic Unit I consists primarily of dark olive-gray diatomaceous mud containing thin laminae of yellow-brown diatom ooze. This mud has a high silt content of between $20 \%$ to $40 \%$. Diatoms make up $20 \%$ to $40 \%$ of the mud and are concentrated in the thin, yellow-brown laminae. The unit has a distinctly laminated character, although an interval of bioturbated sediment is present between 12 to 15 mbsf. (Fig. 3).

Hole 686A: Lithologic Unit I consists mainly of sandy diatomaceous muds that are predominantly, but not exclusively laminated. These muds have $20 \%$ to $55 \%$ diatom frustules, $10 \%$ to $55 \%$ clay minerals, and $0 \%$ to $30 \%$ sandsized terrigenous grains (Fig. 3). Laminated muds are of two basic types: Type 1 lamination where laminae are thicker than $0.5 \mathrm{~cm}$ and Type 2 lamination where laminae are generally thinner, less than $0.5 \mathrm{~cm}$.

Our samples were taken by scraping with a 7.5 -cm-long microscopical slide across cleaned archive halves of cores without disturbing and removing noticeable amounts of sediment from the archive cores. Samples did slightly overlap at their upper and lower boundaries. Thus, a complete section of continuous channel samples was retrieved from the holes to approximately $37.72 \mathrm{~m}$ at Hole 686A and $52.69 \mathrm{~m}$ at Hole $681 \mathrm{~A}$ 
Table 1. Location of sites and coring data.

\begin{tabular}{lccccc}
\hline Hole & $\begin{array}{c}\text { Longitude } \\
\text { (degrees) }\end{array}$ & $\begin{array}{c}\text { Latitude } \\
\text { (degrees) }\end{array}$ & $\begin{array}{c}\text { Depth } \\
\text { of water } \\
(\mathrm{m})\end{array}$ & $\begin{array}{c}\text { Intervals studied } \\
\text { sed. str. }{ }^{\mathrm{a}} \text { microp. } \\
\text { (mbsf) }\end{array}$ \\
\hline $681 \mathrm{~A}$ & $1058.60 \mathrm{~S}$ & $7757.56 \mathrm{~W}$ & 150.5 & $0.66-15.5$ & $0.66-5.08$ \\
$686 \mathrm{~A}$ & $1328.81 \mathrm{~S}$ & $7653.49 \mathrm{~W}$ & 446.8 & $0.00-23.5$ & $6.60-9.60$ \\
& & & & & $14.60-23.22$
\end{tabular}

a sed. str. = sedimentary structures.

$\mathrm{b}$ microp. $=$ micropaleontology.

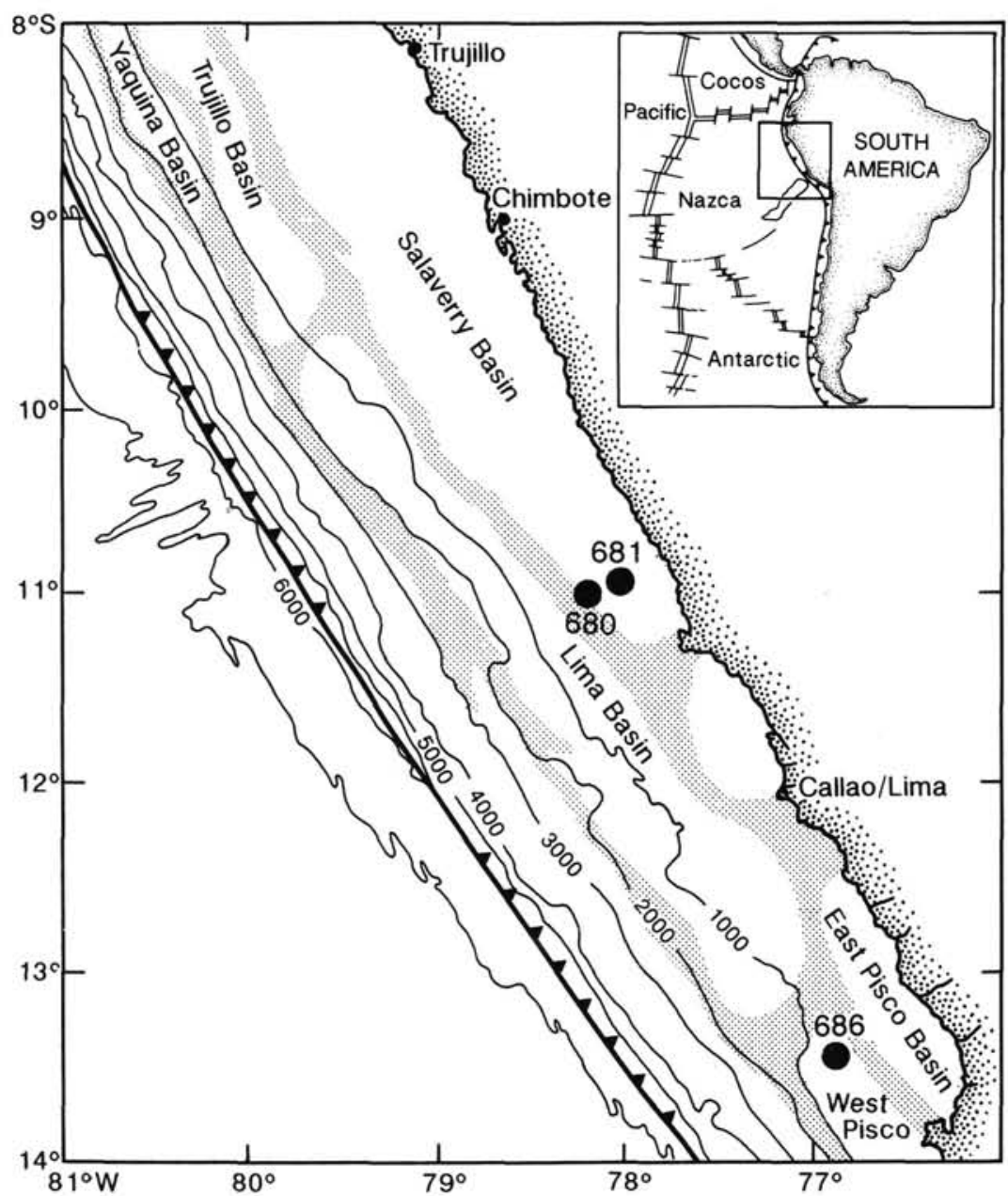

Figure 1. Location of Holes $681 \mathrm{~A}$ and $686 \mathrm{~A}$ on the Peruvian continental margin. Depth contours in (m), from Hussong et al. (1985).

(see Table 1 and Fig. 3 for sampling intervals). Individual channel samples represent about 750 to $1500 \mathrm{yr}$ of deposition, assuming a sedimentation rate of 5 to $10 \mathrm{~cm} / \mathrm{k} . \mathrm{y}$. on the average for both sites.

Sediment structures were determined from both the cleaned surface of the archive halves of the cores and from uncleaned archive core photographs (which in the latter case made interpretation less accurate). The downcore variation of sediment structures in the illustrations (Figs. 4, 5, and 6) used here is based on a combination of core photographs and direct inspection of cleaned archive halves of the surfaces. These structures were grouped into two categories: (1) intervals having no visible lamination over $7.5-\mathrm{cm}$ sampling intervals were grouped into the homogeneous/bioturbated category, and (2) intervals showing laminae at 7.5 -cm sample spacing were grouped into the laminated category.

Micropaleontological channel samples were cleaned and quantitative diatom mounts were prepared following the procedures of Gersonde (pers. comm., 1988); these were mounted in the high-refractive index mounting medium PL/2 (Schrader); counting followed the convention outlined in Schrader and Gersonde (1978). Absolute numbers of diatoms are presented in values $10^{6}$ per gram of dry sediment. On average, 350 diatom units were counted per sample.

Some samples (only from Hole 686A,) were removed from the original data set before further statistical treatment because of the scarcity of diatoms. These samples included Hole $686 \mathrm{~A}$ interval $112-686 \mathrm{~A}-2 \mathrm{H}-2,45-52.5 \mathrm{~cm}$, to $112-686 \mathrm{~A}-2 \mathrm{H}-2$, 


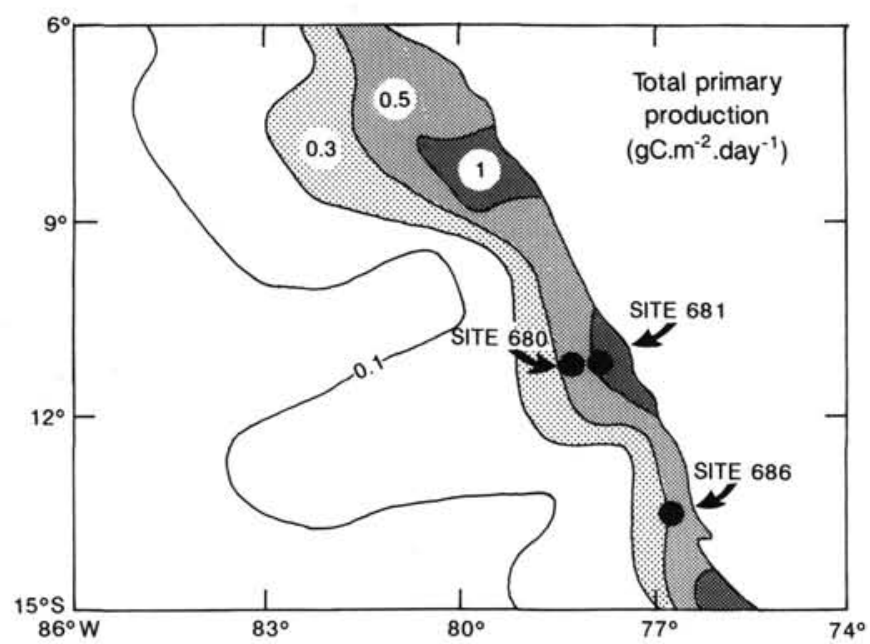

Figure 2. Distribution of 10-yr averaged primary production along the Peruvian continental margin, from Zuta and Guillen (1970); location of Sites 681 and 686 .

$37.5-45 \mathrm{~cm}$; $112-686 \mathrm{~A}-2 \mathrm{H}-3,15-22.5 \mathrm{~cm}$, to $112-686 \mathrm{~A}-2 \mathrm{H}-3$, $82.5-90 \mathrm{~cm} ; 112-686 \mathrm{~A}-3 \mathrm{H}-2,52.5-60 \mathrm{~cm}$, to $112-686 \mathrm{~A}-3 \mathrm{H}-3$, $30-37.5 \mathrm{~cm}$ (see Fig. 6 and Table 2).

A total of 27 taxonomic entities were distinguished in the samples, and the taxonomy followed that of Schuette and Schrader (1981a, 1981b), with the following exceptions; Thalassiosira species containing Thalassiosira decipiens, T. kryophila, and a few other Thalassiosira species that could not be identified; Actinoptychus including A. splendens and A. senarius; Actinocyclus species having a distinct pseudonodulus; Nitzschia species, including Nitzschia marina, Nitzschia seriata, and Nitzschia interrupta; Cyclotella species, including $C$. striata and $C$. stylorum; unidentified Rhaphoneis and Opephora species, and Asteromphalus species, including $A$. robustus and $A$. arachne.

\section{RESULTS}

\section{Sedimentary Structures}

Sedimentary structures were grouped into two categories. These categories were defined on the basis of approximately $7.5-\mathrm{cm}$-spaced sampling intervals and differ from the results presented in the Leg 112 site chapters (Suess, von Huene, et. al., 1988) by providing greater detail. The laminated intervals include a variety of different laminations, ranging from very finely laminated intervals with submillimeter-thick darker and lighter laminae to sections with thicker laminae ( Shipboard Scientific Party, 1988, Figs. 10 through 14, p. 714-716). The finely laminated intervals (Shipboard Scientific Party, 1988, Fig. 11, p. 714) are similar to marine varves (Baumgartner et al., 1985, Schrader, 1987), whereas some of the intervals with thick lighter laminae represent mass accumulation of monospecific diatom assemblages owing to mass production over several seasons and/or from winnowing processes on the bottom that sorted grains of similar hydraulic properties.

Downcore variation of sedimentary structures are plotted in Figure 4 for Holes $681 \mathrm{~A}$ and 686A. The alternation of laminated vs. homogeneous intervals in both cores corresponds well between the two sites, in that similar sedimentary structures occur at similar downcore depths. The top of Hole $681 \mathrm{~A}$ seems to have collected the most recent sediments, whereas the top of Hole 686A seems to have missed the top portion (approximately $1 \mathrm{~m}$ is missing). This interpretation is supported by observations at Hole $686 \mathrm{~A}$ indicating laminated and less-watery sediments were recovered near the top. Water content and porosity at Hole $686 \mathrm{~A}$ are substantially lower than at Hole $681 \mathrm{~A}$ (at Hole $681 \mathrm{~A}$ water content is $270 \%$ of dry weight, with $90 \%$ porosity, compared with $100 \%$ to $150 \%$ water content and $80 \%$ to $90 \%$ porosity at Hole $686 \mathrm{~A}$ (Shipboard Scientific Party, 1988).

We have differentiated the different structures at both sites in Figures 5 and 6 to represent laminated intervals and homogeneous intervals. The boundaries from predominantly bioturbated intervals to laminated intervals are indicated by solid lines, whereas the boundaries from laminated to homogeneous sections are plotted by wavy lines. Wavy lines and solid lines indicate major long-term shifts of bottom-water conditions, with shifts from predominantly oxic conditions to predominantly anoxic conditions and vice versa. The boundaries indicating shifts from anoxic to oxic bottom-water conditions may have been secondarily shifted downward, as indicated by high diatom numbers in overlying sediment. We interpret these homogeneous intervals with high diatom numbers as secondarily bioturbated intervals. The boundaries from homogeneous to laminated facies, on the other hand, are sharp and may be unaltered, as indicated by the pronounced changes in the diatom number.

\section{Dating}

Little direct data are available to date the Quaternary sections recovered at Holes 681A and 686A. Averaged sedimentation rates are calculated for $681 \mathrm{~A}$ as on the order of $80 \mathrm{~m} / \mathrm{m}$.y. for the Brunhes/Matuyama boundary to the Holocene; rates calculated for Hole $686 \mathrm{~A}$ are at least $160 \mathrm{~m} / \mathrm{m} . \mathrm{y}$., according to nannoplankton data (Shipboard Scientific Party, 1988). De Vries and Pearcy (1982) calculated average sedimentation rates of $2 \mathrm{~cm} / \mathrm{k} . \mathrm{y}$. for the Holocene interval for cores located near the present ODP sites. Cycle stratigraphy (based on Haq et al., 1987), as proposed for Site 686 (Shipboard Scientific Party, 1988) revealed a sedimentation rate of $60 \mathrm{~m} / \mathrm{m}$.y. for lithologic Unit I ( 0 to $28 \mathrm{mbsf}$ ). The location of the Brunhes/Matuyama boundary, dated at $730,000 \mathrm{yr}$, may be at 82 to $84 \mathrm{mbsf}$ at Hole $681 \mathrm{~A}$ (resulting in a sedimentation rate of $113 \mathrm{~m} / \mathrm{m} . \mathrm{y}$.) and at $45 \mathrm{mbsf}$ at Hole $686 \mathrm{~A}$ (resulting in a sedimentation rate of $62 \mathrm{~m} / \mathrm{m} . \mathrm{y}$.). Because R. McCabe cautioned against relying on the paleomagnetic reversal stratigraphy, (see Shipboard Scientific Party, 1988), we do not place much reliance in these data.

Oberhaensli et al. (this volume) and Wefer et al. (this volume) proposed an oxygen-isotope stratigraphy based on the benthic foraminifer Bolivina sp. for Hole 680B over oxygen isotope Stages 1 through 11 . They extended this stratigraphy beyond the Stage 11 boundary, using the covariance of the amount of the coarse fraction with the stable isotopes.

We adopted the general oxygen-isotope stratigraphy proposed by Wefer et al. and Oberhaensli et al. (this volume) for Hole 680B. A detailed correlation between Holes 680B, 681A, and $686 \mathrm{~A}$ was recently defined (Schrader and Sorknes, unpubl. data) based on sedimentary features and occurrence of unique diatom floral assemblages. The last occurrence of Delphineis "ossiformis" (an undescribed new Delphineis species) was used to correlate oxygen-isotope Stage 10/11 in Holes $680 \mathrm{~B}, 681 \mathrm{~A}$, and $686 \mathrm{~A}$. This correlation was our basis to infer oxygen-isotopic Stages at Hole 681A and 686A and establish a chronology in these two holes using the chronology proposed by Imbrie et al. (1984) and Prell et al. (1986).

Averaged sedimentation rates can be calculated for Sites 681 and 686 by placing oxygen-isotope Stage boundary $7 / 8$ at $15 \mathrm{mbsf}$ at Hole $681 \mathrm{~A}$ and stage boundary $7 / 8$ at $19 \mathrm{mbsf}$ at Site 686; these rates are $61.4 \mathrm{~m} / \mathrm{m}$.y. for Hole $681 \mathrm{~A}$ and 77.8 $\mathrm{m} / \mathrm{m}$.y. for Hole 686A (adjusted for an approximate loss of $1 \mathrm{~m}$ of surficial sediment at the top). 

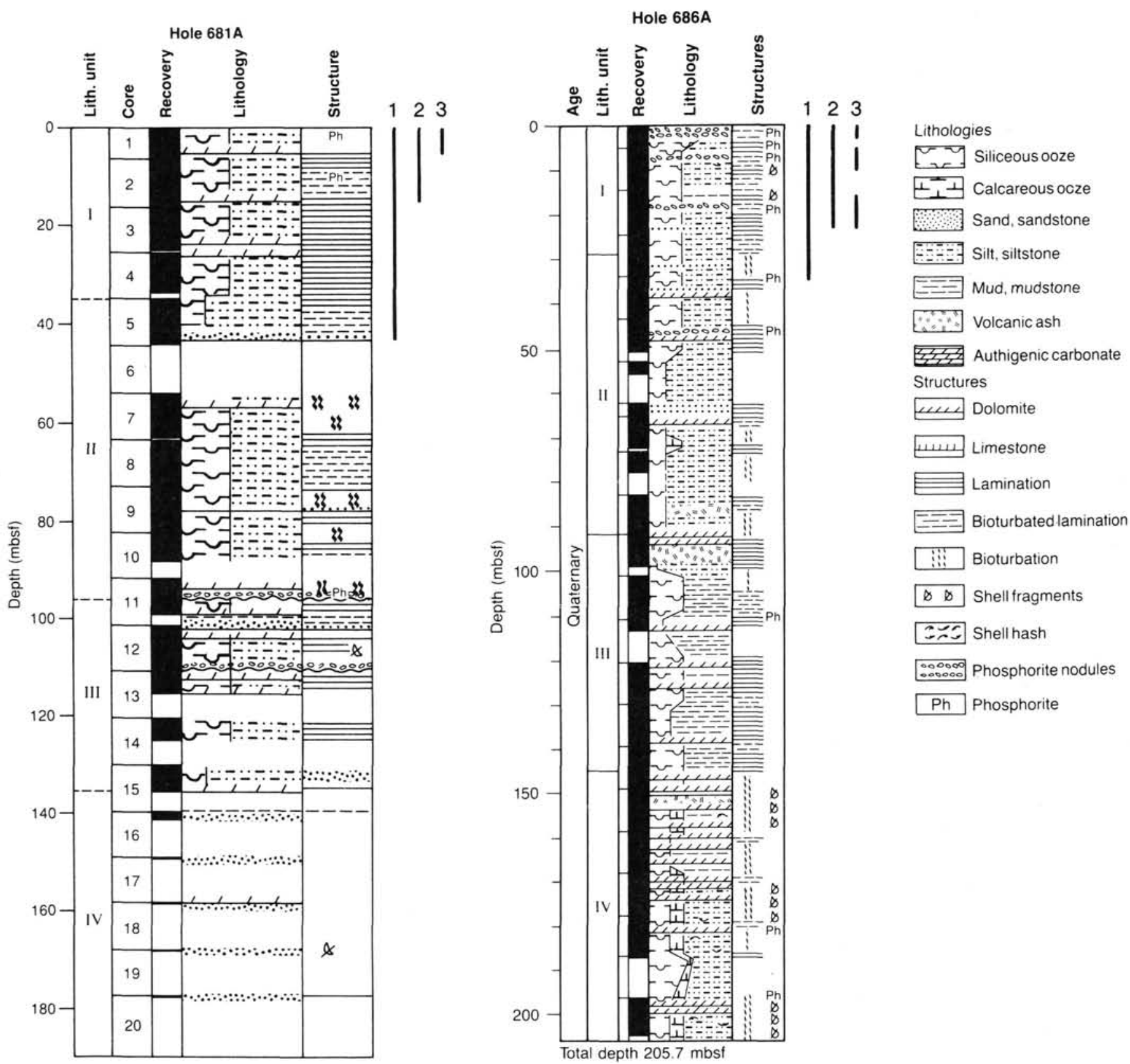

Figure 3. General sedimentology and sedimentary structures of Holes 681A and 686A, from Shipboard Scientific Party (1988). Thick bars to left of cores indicate (1) sampled interval, (2) detailed sedimentary structures sampled at $7.5-\mathrm{cm}$ intervals, and (3) continuous sections studied here for micropaleontology.

The record of high sedimentation rate at both sites is frequently disturbed by graded beds with sharp contacts, phosphorite and dolomite horizons, and sand and ash layers, all indicative of periodic strong bottom-current activities and indicative of mini-hiatuses and turbiditic horizons. Our analyses does not permit us to define and interpret possible time gaps in the record of the last $400,000 \mathrm{yr}$.

\section{Abundance and Preservation of Diatoms}

Diatom abundances at Hole $681 \mathrm{~A}$ vary between 0 to $33 \times$ $10^{6}$ valves per gram of dry sediment (Fig. 5). In general, diatom numbers are higher at Hole $681 \mathrm{~A}$ with maximum values of 33 and an average of $10 \times 10^{6}$, compared with Hole 686A (Fig. 6), where maximum values approach only 18 million valves per gram of dry sediment (average is $3 \times 10^{6}$ ).
Assuming an average sedimentation rate of $6.14 \mathrm{~cm} / \mathrm{k} . \mathrm{y}$. an average bulk density of $1.4 \mathrm{~g} / \mathrm{cm}^{3}$, an average water content of $80 \%$, and an average of 10 million valves per gram of dry sediment for the interval 0 to $14.5 \mathrm{~m}$ at Hole $681 \mathrm{~A}$, a diatom-valve accumulation rate of 17 million valves per $\mathrm{cm}^{2}$ per 1000 years can be calculated. This value is almost double that at Hole 686A (assuming a sedimentation rate of 7.78 $\mathrm{cm} / \mathrm{k} . \mathrm{y}$., an average dry bulk density of $1.45 \mathrm{~g} / \mathrm{cm}^{3}$, and an average water content of $73 \%$ over the top $15 \mathrm{~m}$, resulting in a diatom accumulation rate of 9 million valves $/ \mathrm{cm}^{2} / \mathrm{k} . \mathrm{y}$.).

Preservation is generally excellent, and even very delicate frustules are preserved with Ditylum, Skeletonema, and Delphineis. Highest diatom numbers were frequently encountered in the laminated intervals, whereas bioturbated intervals showed lower numbers (Figs. 5 and 6). Bioturbated intervals 


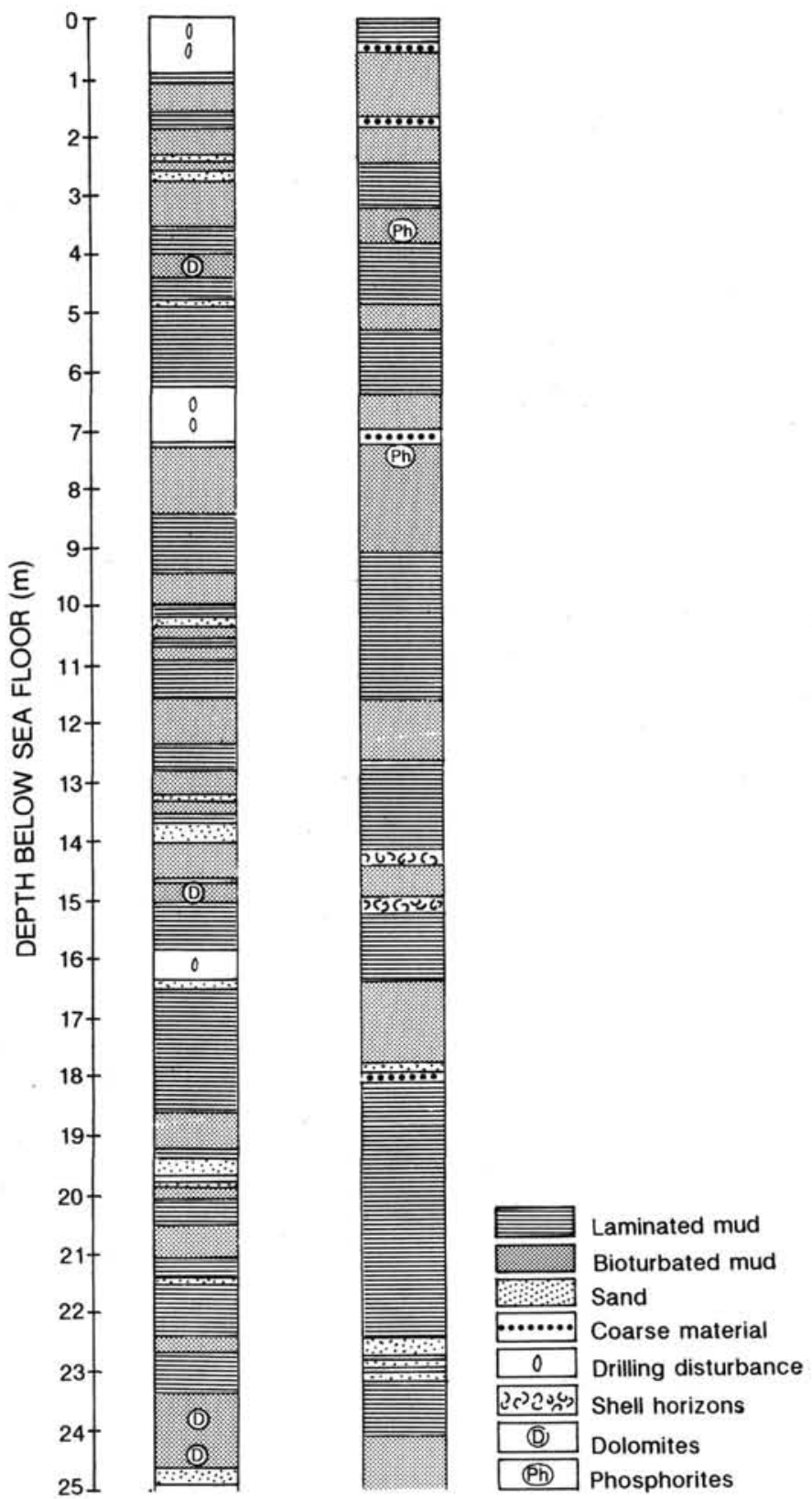

Figure 4. Sediment structures at Holes $681 \mathrm{~A}$ and $686 \mathrm{~A}$, based on interpretation from cleaned archive halves of cores and from core photographs of uncleaned archive halves. Sampling interval is in $7.5-\mathrm{cm}$ increments.

having high numbers of diatom frustules and excellent preservational states of delicate diatoms are interpreted to represent sediment structures that initially were laminated and became subsequently bioturbated when changing from a predominantly anoxic bottom-water environment to an oxygenated one (Fig. 5 , between 4 to $4.25 \mathrm{mbsf}$ ). We postulate that the boundaries from an oxic bottom-water environment to an anoxic environment, as they are recorded in the sedimentary column, are stable and were not subjected to secondary mixing processes.

\section{Diatom Assemblages}

Because all diatom-bearing samples (for general statistics see Table 2, consult Table 3 for listing of all diatom-bearing samples studied) contained large quantities of Chaetoceros

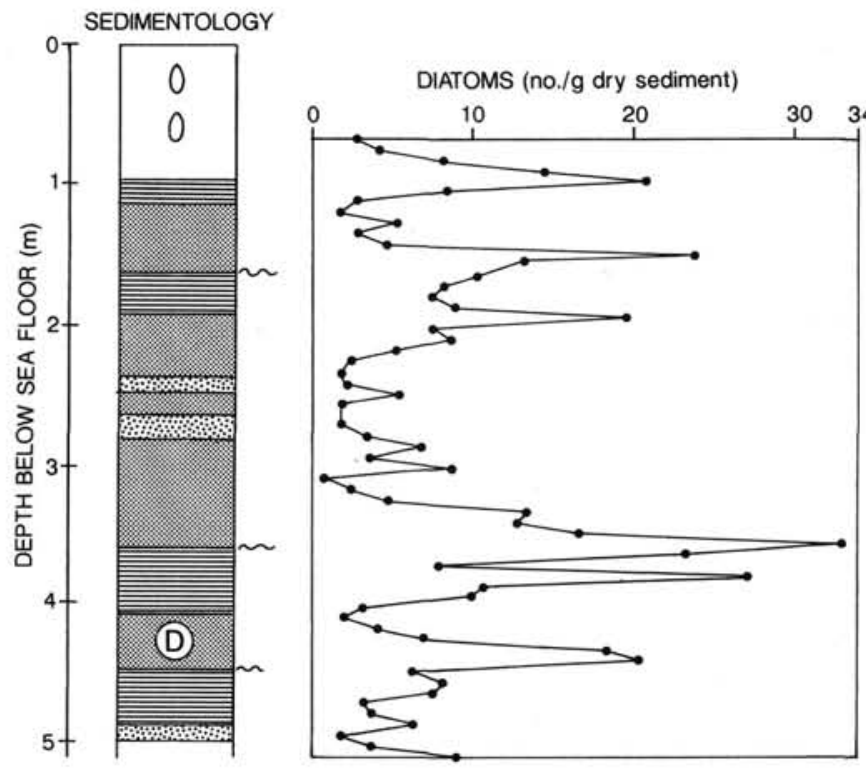

Figure 5. Comparison of sediment structures (subdivided into laminated and homogeneous intervals) with diatom abundances in number of valves per gram dry sediment $\times 10^{6}$ at Hole $681 \mathrm{~A}$. Note diatom numbers are plotted only for the interval from 0.6 to $5.08 \mathrm{mbsf}$ in Core $112-681 \mathrm{~A}-1 \mathrm{H}$

resting spores, the environmental signal retrieved from other species might be biased; thus, we removed the Chaetoceros resting spores from most of our results.

Three major groups were defined from the Chaetoceros resting-spore free data base; these group definitions follow closely those defined by DeVries and Schrader (1981) and Schuette and Schrader (1979a). The percentage of distribution is plotted downcore in Figure 7, and values are tabulated in Table 3.

A warm-water group, consisting of Thalassionema nitzschioides var. parva, Rhizosolenia bergonii, Pseudoeunotia doliolus, Roperia tesselata, and Coscinodiscus nodulifer (=Azpeitzia nodulifer), is plotted in Figure 7C. Peaks in this warm-water group with values over $10 \%$ (see Table 3) occur at the following intervals: Hole $681 \mathrm{~A}, 0.66,0.95-1.10$, $1.63-1.78,2.00-2.37$, and 2.90-3.03 mbsf, and at Hole $686 \mathrm{~A}, 20.37,21.20-21.50$, and 21.82-22.25 mbsf.

Warm-water assemblages occur both within laminated intervals and in homogeneous intervals. Pronounced occurrences of this group are found in oxygen-isotopic Stages 2, 6, and 10. During these times, increased influence of warm surface waters must have taken place.

The neritic assemblage, consisting of Coscinodiscus asteromphalus, Actinoptychus undulatus, A. splendens, Stephanopyxis turris, Actinocyclus ehrenbergii, Cyclotella striatal stylorum, and Rhaphoneis spp., had maximum occurrences (above 30\%) at the following levels (Fig. 7B, Table 3): Hole $681 \mathrm{~A}, 0.87-1.17,2.75,3.10,4.02,4.38,4.83-5.06 \mathrm{mbsf}$, and Hole $686 \mathrm{~A}, 6.67,8.40,8.62$ (maximum value of $83.33 \%$ ), 9.22, $16.10,16.25-16.32,19.02-19.10,20.60,20.82-21.65,21.87$, 22.70 , and 23.00 mbsf.

This neritic assemblage is one member of the upwelling diatom pool and therefore occurs in both the homogeneous and the laminated intervals, giving evidence for the generally high primary productivity along the Peruvian continental margin during the last $400,000 \mathrm{yr}$.

The upwelling group, including Delphineis karstenii, Sceletonema costatum, and Ditylum brightwellii, has its highest peaks (over 50\%) at the following levels (Fig. 7A, Table 3): Hole 681A, 


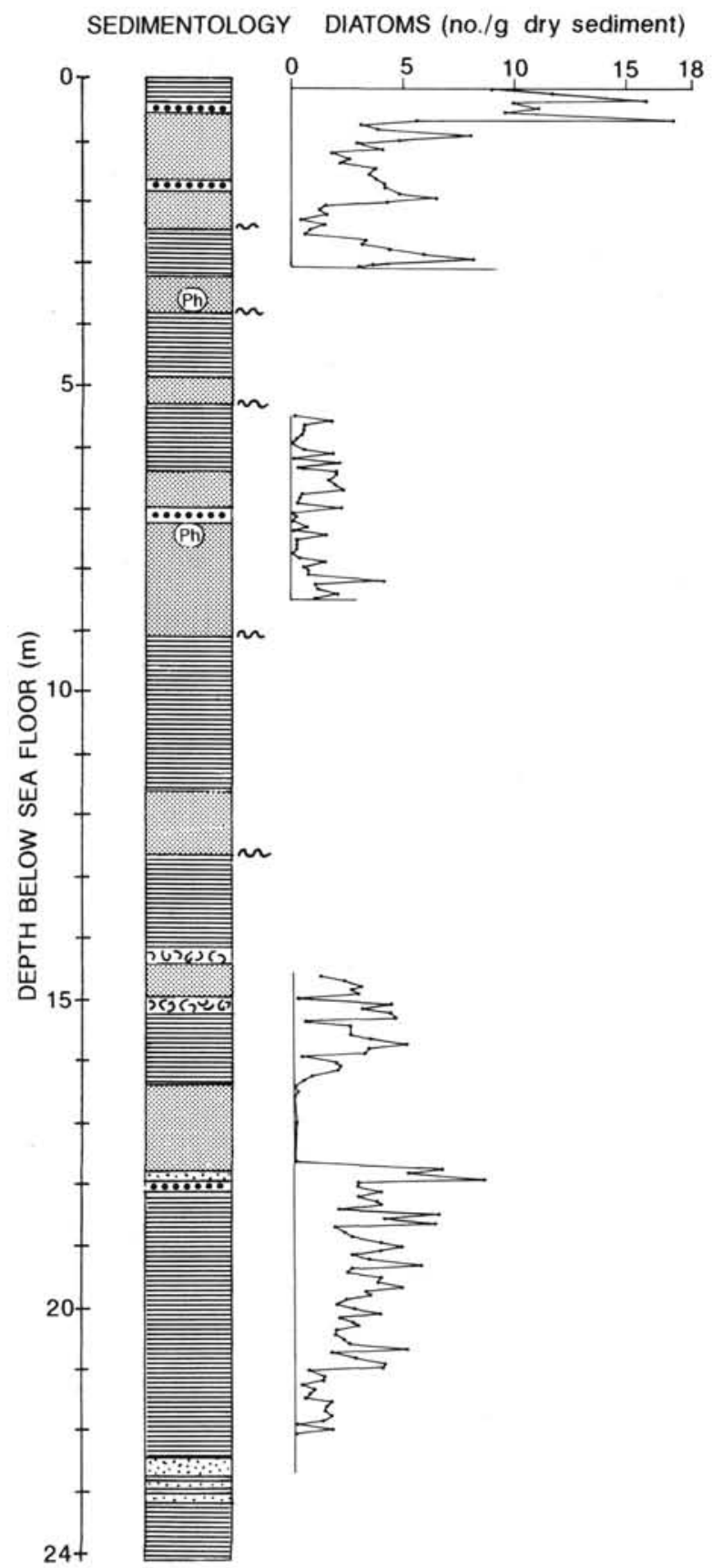

Figure 6. Comparison of sediment structures (subdivided into laminated and homogeneous intervals) with diatom abundances in number of valves per gram dry sediment $\times 10^{6}$ at Hole $686 \mathrm{~A}$. Note diatom numbers are plotted only for the intervals from 0.0 to $3.08,6.6$ to 9.6 , and 14.60 to 23.22 mbsf in Cores $112-686 \mathrm{~A}-1 \mathrm{H}$ through $112-686 \mathrm{~A}-3 \mathrm{H}$.

$1.93,3.32-3.94$ mbsf, and at Hole 686A, 7.65-8.10, 8.70, 9.37$9.60,14.60-14.90,15.57,18.05-18.95,19.47-19.70$ mbsf.

Highest values for this upwelling group occur within the finely laminated sections at Holes $681 \mathrm{~A}$ and $686 \mathrm{~A}$, during oxygen-isotopic Stages 1, 3, 5, 7, and 8 .

\section{Factor Analysis}

To reduce the large amount of information contained in these data, we applied Q-mode factor analysis (Extended Cabfac Deluxe Version, based on Klovan and Imbrie, 1971; Deluxe Version by Bill Full, Univ. South Carolina, latest revision 20/12/1980, Ehrlich and Full, 1987) to the data base and developed two models. Model 1 contained all 27 species (Table 2). In contrast, Model 2, is based on a reduced variable list. The following species were removed from the database: Chaetoceros resting spores, Stephanopyxis turris, Nitzschia species, Actinocyclus species, Roperia tesselata, Rhaphoneis species, Opephora species, and Asteromphalus species. These species, with the exception of Chaetoceros resting spores, occur only sporadically (Table $2,{ }^{*}$ species have been removed).

Model 1, including all 27 variables, resulted in two factors that accounted for $95.10 \%$ of the variance in the data set. Factor 1 consisted of Chaetoceros resting spores, and Factor 2 consisted primarily of Skeletonema costatum and Thalassionema nitzschioides. Factor loadings for Factor 1 are plotted downcore in Figure 8. Factor 1 loadings were generally high over the entire interval, with several zones where factor loadings decreased substantially; these are Hole 681A, at 1.5, at 3.5 , and at 4.75 mbsf; Hole $686 \mathrm{~A}$, at $18.75,19.5,20.75$, and at 22.25 mbsf. These decreases in Factor 1 loadings correspond to intervals where predominantly laminated sediments prevail, except for the interval at Hole 686A at $22.25 \mathrm{mbsf}$, where a thin, bioturbated/homogeneous section is intercalated into predominantly laminated sediments.

The decreases in Factor 1 loadings are compensated by a high loading of Factor 2. Both factors are essentially upwelling indicative and manifest the persistent coastal upwelling influence over the entire section with diatom-bearing samples.

Model 2 included 18 variables and generated five factors (Table 4, Fig. 9) that accounted for $91 \%$ of the total variance. Factor 1 consisted of Thalassionema nitzschioides, Factor 2 of Delphineis karstenii, Factor 3 of Skeletonema costatum, Factor 4 of Actinoptychus undulatus and splendens and Thalassiosira leptopus, and Factor 5 of Thalassiosira eccentrica. (Factor loadings downcore are plotted in Fig. 9.)

In their downcore loadings, the strong upwelling Factors 2 and 3 follow the general trend, as it is illustrated in the downcore plot of the upwelling group (Fig. 7A). Maximum loadings of these two factors are halved for the Skeletonema factor in Hole 686A. Because Delphineis does not commonly occur in Hole 681A, the loading of the Delphineis factor at that hole is minimal.

Based on diatom abundance, their occurrence within finely laminated intervals, and on statistical groupings, we propose the following scenario for a species succession as revealed from sediments during the aging of an upwelling system: (1) it drifts away from its origin of upwelling, (2) it warms, and (3) it is depleted in nutrients. The juvenile diatom flora consists of Skeletonema, Delphineis, Ditylum; this flora is succeeded by Thalassionema, Actinoptychus, and finally this flora is succeeded by Chaetoceros. These results compare favorably with those of Schuette and Schrader (1979a) and DeVries and Schrader (1981).

\section{DISCUSSION}

Results presented here document the continuous change of sedimentary and micropaleontological signals in composite samples spanning, on the average, 750 to $1500 \mathrm{yr}$ each. Short-lived changes producing spiked signals have been averaged in our data set, but our data set provides a complete record of environmental and sedimentological change over the last $400,000 \mathrm{yr}$.

Finely laminated sedimentary units with submillimeterscaled lighter and darker laminae occur frequently downcore, and these sedimentary structures are essentially absent from Holocene shelf and upper-slope facies off Peru. Soutar et al. 
Table 2. General statistics of diatom-assemblage census data.

\begin{tabular}{|c|c|c|c|c|}
\hline Average & $\begin{array}{l}\text { Standard } \\
\text { deviation }\end{array}$ & $\begin{array}{l}\text { Minimum } \\
\text { value }\end{array}$ & $\begin{array}{l}\text { Maximum } \\
\text { value }\end{array}$ & Species name \\
\hline 232.4918 & 112.4452 & 24.0 & 554.0 & Chaetoceros spores* \\
\hline 2.9727 & 4.9692 & 0 & 31.0 & Thalassionema nitzschioides var, parva \\
\hline 28.8525 & 29.6317 & 0 & 163.0 & T. nitzschioides \\
\hline 13.5683 & 14.0617 & 0 & 100.0 & Thalassiosira eccentrica \\
\hline 5.4863 & 11.0389 & 0 & 50.0 & T. leptopus \\
\hline 1.1639 & 1.9320 & 0 & 13.0 & T. oestrupii \\
\hline 2.6667 & 8.5554 & 0 & 97.0 & Thalassiosira spec. 01 \\
\hline 3.2842 & 4.2059 & 0 & 30.0 & Coscinodiscus radiatus \\
\hline 1.1148 & 1.6273 & 0 & 10.0 & C. asteromphalus \\
\hline 20.4536 & 41.4867 & 0 & 288.0 & Delphineis karstenii \\
\hline 27.8197 & 55.5906 & 0 & 344.0 & Skeletonema costatum \\
\hline 1.7923 & 2.2252 & 0 & 11.0 & Rhizosolenia bergonii \\
\hline 19.8470 & 19.3701 & 0 & 103.0 & Actinoptychus species \\
\hline 1.5301 & 2.2294 & 0 & 12.0 & Pseudoeunotia doliolus \\
\hline 0.3989 & 1.0293 & 0 & 7.0 & Stephanopyxis turris* \\
\hline 1.3934 & 2.3995 & 0 & 18.0 & Actinocyclus ehrenbergii \\
\hline 0.2896 & 0.8153 & 0 & 7.0 & Nitzschia sp.* \\
\hline 0.9290 & 1.7463 & 0 & 13.0 & Thalassiothrix longissi \\
\hline 2.8907 & 5.5652 & 0 & 52.0 & Ditylum brightwellii \\
\hline 0.3443 & 0.8142 & 0 & 4.0 & Actinocyclus sp. ${ }^{*}$ \\
\hline 0.2350 & 0.7571 & 0 & 6.0 & Roperia tesselata* \\
\hline 2.1858 & 7.7261 & 0 & 55.0 & Cyclotella sp. \\
\hline 0.9399 & 4.9447 & 0 & 52.0 & Coscinodiscus nodulifer \\
\hline 0.5246 & 1.2667 & 0 & 8.0 & Rhaphoneis sp.* \\
\hline 0.3716 & 0.9715 & 0 & 5.0 & Opephora sp.* \\
\hline 0.1366 & 0.4284 & 0 & 3.0 & Asteromphalus sp.* \\
\hline 0.8415 & 8.3419 & 0 & 108.0 & Delphineis karstenii \\
\hline
\end{tabular}

Starred species were removed from the Model 2 factor analysis.

(1982) offered three explanations for the absence of laminated Holocene sediments off Peru. These include (1) bottomcurrents with high velocities winnow and redistribute sediment components (maximum near-bottom velocities of 70 $\mathrm{cm} / \mathrm{s}$ have been measured); (2) a mobile population of the pelagic red crab Pleuroncodes invades the upper-slope/shelf mud lens during periodic cessation of anoxic bottom-water conditions and mixes the primary lamination of surficial sediments down to $1 \mathrm{~cm}$, and (3) a general lack of seasonally different terrigenous and pelagic influx to form visible alternating layering. Soutar et al.(1982) and DeVries (1979) pointed to a possible dramatic change in the sedimentation within the mud lens below the Holocene, where laminated sediments seem to occur regularly.

Except for a few sandy, well-graded horizons, the homogeneous intervals do not seem to represent lag deposits; they are unsorted and contain a typical texture of shelf and slope sediments. Their microfossil content of frequently enriched benthic and planktonic foraminifers and an impoverished upwelling diatom signal indicated less organic-matter production and decreased primary production in surficial waters. Thus, we interpret the occurrence of homogeneous/bioturbated intervals as being the result of lowered primary production. This lowered primary production could be responsible for a less-pronounced oxygen-minimum zone intersecting the slope and shelf, and the poorly developed oxygen-minimum zone could allow for a richer benthic infauna to mix up sedimentary influxes.

By contrast, finely laminated intervals are clear indications of increased primary production, with their increased diatom content and their excellently preserved diatom assemblages. Increased proportions of diatom species typically inhabiting strong coastal upwelling environments signal these increased primary production occurrences. Because of the increased amount of organic matter reaching the sediment/water interface and its subsequent oxidation, bottom waters will be depleted of dissolved oxygen and a stable anoxic bottomwater environment will inhibit the development of an infauna, which could bioturbate and homogenize sediment influx signals.

The presence of alternating, submillimeter-thick, light and dark, diatom and clay-rich laminae is a manifestation of a well-developed seasonality of biogenic and terrigenous influxes, which have to be offset from each other. A wetter climate with more runoff and larger contributions of terrigenous material to the shallow shelf basins, while Peru was under the influence of a more southerly climate belt system, was proposed by DeVries and Pearcy (1982), based on evidence presented by Quinn (1971), Colinvaux (1972), and Molina-Cruz (1977). Oberhaensli et al. (this volume) reported increased amounts of coarse-grained, terrigenous material during glacials at Site 680 .

Like DeVries (1979), we noticed an enrichment of warmwater phytoplankton elements during the last glacial period. Other horizons occurred during oxygen-isotopic Stages 6 and 10 , and contained noticeable increases of this warmwater component. No other intervals had similarly strong increases.

The Peruvian diatom pool found in hemipelagic sediments on the continental margin indicative of coastal upwelling consists of (1) Chaetoceros resting spores, (2) Thalassionema nitzschioides, (3) Actinoptychus undulatus/splendens, (4) Cyclotella striata/stylorum, (5) Skeletonema costatum, (6) Delphineis karstenii, and (7) Ditylum brightwellii. The strongest coastal upwelling is signaled by Delphineis, Skeletonema, and Ditylum, less strong upwelling by Cyclotella and Actinoptychus, and weaker upwelling by Thalassionema and Chaetoceros. These three species groups indicate a species succession as it occurs in an altering upwelling plume (Jones et al., 1983), with Skeletonema and Delphineis blooming during the initial stages and Chaetoceros taking over during the later stages.

The composite section from Sites 681 and 686 give evidence to a persistent upwelling phenomenon during the last $400,000 \mathrm{yr}$. Our data indicate that this system prevailed at all times at the 750 - to 1500 -yr-period resolution of our sampling. 
Table 3 . Percentage distribution of three groups - warm-water, neritic, and upwelling-on a Chaetocerosfree basis from Holes 681A and 696A.

\begin{tabular}{|c|c|c|c|}
\hline \multirow[b]{2}{*}{$\begin{array}{l}\text { Depth } \\
\text { (mbsf) }\end{array}$} & \multicolumn{3}{|c|}{ Diatom assemblages } \\
\hline & $\begin{array}{l}\text { warm- } \\
\text { water }\end{array}$ & neritic & upwelling \\
\hline \multicolumn{4}{|c|}{ Hole $681 \mathrm{~A}$} \\
\hline 0.66 & 13.33 & 34.17 & 5.83 \\
\hline 0.74 & 9.50 & 43.00 & 1.50 \\
\hline 0.81 & 9.88 & 25.31 & 3.09 \\
\hline 0.87 & 6.98 & 42.64 & 24.03 \\
\hline 0.95 & 12.16 & 50.68 & 12.84 \\
\hline 1.02 & 3.49 & 58.14 & 5.81 \\
\hline 1.10 & 12.50 & 37.50 & 9.38 \\
\hline 1.17 & 0.00 & 33.33 & 8.33 \\
\hline 1.24 & 2.06 & 20.62 & 19.59 \\
\hline 1.31 & 8.70 & 19.57 & 14.13 \\
\hline 1.39 & 6.55 & 17.86 & 21.43 \\
\hline 1.46 & 5.24 & 4.03 & 66.94 \\
\hline 1.63 & 21.43 & 21.43 & 16.67 \\
\hline 1.70 & 8.86 & 18.99 & 21.52 \\
\hline 1.78 & 10.08 & 10.92 & 16.81 \\
\hline 1.86 & 2.52 & 18.49 & 30.25 \\
\hline 1.93 & 9.55 & 6.37 & 57.32 \\
\hline 2.00 & 35.92 & 13.59 & 19.42 \\
\hline 2.15 & 33.33 & 13.33 & 31.11 \\
\hline 2.22 & 37.35 & 13.25 & 15.66 \\
\hline 2.30 & 20.00 & 27.20 & 16.80 \\
\hline 2.37 & 12.28 & 17.54 & 14.04 \\
\hline 2.44 & 3.16 & 12.63 & 28.42 \\
\hline 2.52 & 8.45 & 14.08 & 36.62 \\
\hline 2.60 & 6.67 & 6.67 & 47.78 \\
\hline 2.67 & 3.51 & 28.07 & 20.18 \\
\hline 2.75 & 6.12 & 33.67 & 25.51 \\
\hline 2.83 & 7.46 & 23.88 & 26.87 \\
\hline 2.90 & 12.70 & 13.49 & 37.30 \\
\hline 2.96 & 8.97 & 32.05 & 17.95 \\
\hline 3.03 & 10.71 & 14.29 & 39.29 \\
\hline 3.10 & 8.57 & 37.14 & 25.71 \\
\hline 3.18 & 4.97 & 12.42 & 40.37 \\
\hline 3.25 & 6.12 & 7.82 & 48.64 \\
\hline 3.32 & 2.66 & 3.85 & 50.59 \\
\hline 3.40 & 7.30 & 4.13 & 55.56 \\
\hline 3.48 & 1.42 & 3.97 & 72.52 \\
\hline 3.55 & 4.39 & 2.93 & 72.93 \\
\hline 3.63 & 3.23 & 5.81 & 71.94 \\
\hline 3.71 & 8.44 & 6.56 & 61.25 \\
\hline 3.79 & 2.16 & 0.96 & 82.69 \\
\hline 3.87 & 2.50 & 5.25 & 63.25 \\
\hline 3.94 & 2.84 & 2.27 & 70.17 \\
\hline 4.02 & 3.10 & 31.01 & 31.78 \\
\hline 4.09 & 0.49 & 20.00 & 2.44 \\
\hline 4.16 & 1.35 & 13.06 & 2.87 \\
\hline 4.23 & 3.07 & 20.25 & 2.03 \\
\hline 4.30 & 3.29 & 16.45 & 0.00 \\
\hline 4.38 & 4.88 & 34.15 & 1.22 \\
\hline 4.46 & 5.43 & 20.65 & 6.24 \\
\hline 4.53 & 4.88 & 20.73 & 12.75 \\
\hline 4.61 & 0.31 & 4.35 & 25.21 \\
\hline 4.68 & 2.41 & 31.33 & 4.35 \\
\hline 4.76 & 0.00 & 27.66 & 2.13 \\
\hline 4.83 & 2.44 & 51.22 & 2.44 \\
\hline 4.91 & 0.00 & 36.00 & 0.00 \\
\hline 4.98 & 2.26 & 38.35 & 6.02 \\
\hline 5.06 & 4.55 & 36.36 & 2.27 \\
\hline \multicolumn{4}{|c|}{ Hole $686 \mathrm{~A}$} \\
\hline 6.67 & 0.00 & 33.33 & 0.00 \\
\hline 6.75 & 2.08 & 19.79 & 3.13 \\
\hline 6.90 & 3.33 & 23.33 & 2.22 \\
\hline 6.97 & 0.00 & 41.18 & 1.18 \\
\hline 7.05 & 9.09 & 18.18 & 9.09 \\
\hline 7.27 & 0.00 & 25.00 & 30.00 \\
\hline 7.35 & 0.00 & 7.63 & 32.06 \\
\hline 7.42 & 0.00 & 28.57 & 14.29 \\
\hline 7.50 & 1.02 & 8.16 & 40.82 \\
\hline 7.57 & 6.90 & 20.69 & 10.34 \\
\hline
\end{tabular}

Table 3 (continued).

\begin{tabular}{|c|c|c|c|}
\hline \multirow[b]{2}{*}{$\begin{array}{l}\text { Depth } \\
\text { (mbsf) }\end{array}$} & \multicolumn{3}{|c|}{ Diatom assemblages } \\
\hline & $\begin{array}{l}\text { warm- } \\
\text { water }\end{array}$ & neritic & upwelling \\
\hline 7.65 & 4.49 & 6.74 & 52.81 \\
\hline 7.72 & 2.47 & 17.28 & 57.41 \\
\hline 7.80 & 3.37 & 16.85 & 42.70 \\
\hline 7.87 & 0.00 & 17.39 & 45.65 \\
\hline 7.95 & 8.08 & 14.14 & 53.54 \\
\hline 8.02 & 0.00 & 20.00 & 53.33 \\
\hline 8.10 & 0.00 & 18.18 & 54.55 \\
\hline 8.17 & 0.00 & 0.00 & 18.18 \\
\hline 8.25 & 0.00 & 22.73 & 40.91 \\
\hline 8.40 & 0.00 & 33.33 & 22.22 \\
\hline 8.55 & 0.00 & 28.57 & 33.33 \\
\hline 8.62 & 0.00 & 83.33 & 0.00 \\
\hline 8.70 & 5.00 & 17.50 & 51.25 \\
\hline 8.77 & 5.56 & 22.22 & 44.44 \\
\hline 8.92 & 0.00 & 9.38 & 40.63 \\
\hline 9.07 & 0.00 & 17.65 & 47.06 \\
\hline 9.15 & 5.77 & 28.85 & 28.85 \\
\hline 9.22 & 1.41 & 33.80 & 26.76 \\
\hline 9.30 & 0.00 & 15.79 & 47.37 \\
\hline 9.37 & 1.82 & 16.36 & 52.73 \\
\hline 9.45 & 0.63 & 4.43 & 81.01 \\
\hline 9.52 & 1.67 & 14.17 & 51.67 \\
\hline 9.60 & 8.00 & 6.00 & 60.00 \\
\hline 14.60 & 4.80 & 11.20 & 55.20 \\
\hline 14.67 & 1.43 & 12.86 & 60.00 \\
\hline 14.75 & 2.94 & 8.82 & 67.65 \\
\hline 14.90 & 2.08 & 8.33 & 52.78 \\
\hline 14.97 & 4.08 & 15.65 & 39.46 \\
\hline 15.05 & 0.00 & 14.06 & 29.69 \\
\hline 15.20 & 3.90 & 16.88 & 24.68 \\
\hline 15.27 & 0.00 & 25.00 & 14.29 \\
\hline 15.35 & 6.20 & 13.18 & 22.48 \\
\hline 15.42 & 2.38 & 3.97 & 33.33 \\
\hline 15.50 & 4.27 & 6.10 & 39.02 \\
\hline 15.57 & 3.75 & 8.75 & 54.38 \\
\hline 15.65 & 0.00 & 21.05 & 42.11 \\
\hline 15.72 & 3.16 & 20.00 & 21.05 \\
\hline 15.80 & 7.09 & 15.75 & 27.56 \\
\hline 15.87 & 2.52 & 13.45 & 10.92 \\
\hline 15.95 & 3.03 & 17.17 & 20.20 \\
\hline 16.03 & 1.47 & 27.94 & 11.03 \\
\hline 16.10 & 1.44 & 33.81 & 10.07 \\
\hline 16.17 & 4.55 & 18.18 & 19.70 \\
\hline 16.25 & 0.00 & 43.48 & 17.39 \\
\hline 16.32 & 0.00 & 37.29 & 10.17 \\
\hline 16.40 & 2.04 & 20.41 & 32.65 \\
\hline 16.47 & 0.00 & 24.00 & 16.00 \\
\hline 16.55 & 0.00 & 8.33 & 16.67 \\
\hline 16.62 & 0.00 & 0.00 & 33.33 \\
\hline 18.05 & 1.96 & 11.76 & 80.07 \\
\hline 18.12 & 2.68 & 12.93 & 73.90 \\
\hline 18.20 & 3.04 & 8.78 & 79.73 \\
\hline 18.27 & 1.55 & 16.06 & 62.18 \\
\hline 18.35 & 4.06 & 7.19 & 58.44 \\
\hline 18.42 & 3.87 & 10.97 & 60.65 \\
\hline 18.50 & 4.22 & 16.87 & 51.81 \\
\hline 18.57 & 5.88 & 9.41 & 68.24 \\
\hline 18.65 & 5.35 & 10.16 & 48.66 \\
\hline 18.72 & 0.00 & 27.50 & 52.50 \\
\hline 18.80 & 3.97 & 11.92 & 52.98 \\
\hline 18.87 & 0.00 & 17.82 & 58.91 \\
\hline 18.95 & 5.49 & 8.63 & 53.33 \\
\hline 19.02 & 2.27 & 31.82 & 29.55 \\
\hline 19.10 & 1.85 & 30.56 & 26.85 \\
\hline 19.17 & 3.97 & 16.67 & 42.06 \\
\hline 19.25 & 1.66 & 9.67 & 30.66 \\
\hline 19.32 & 7.80 & 22.02 & 29.36 \\
\hline 19.40 & 3.23 & 21.29 & 41.29 \\
\hline 19.47 & 2.41 & 15.66 & 51.20 \\
\hline 19.55 & 3.45 & 17.67 & 37.07 \\
\hline 19.62 & 5.03 & 7.26 & 53.07 \\
\hline 19.70 & 3.68 & 19.47 & 51.58 \\
\hline 19.77 & 4.78 & 21.66 & 28.03 \\
\hline 19.85 & 7.27 & 20.61 & 35.15 \\
\hline 19.92 & 0.54 & 16.13 & 28.23 \\
\hline
\end{tabular}

Table 3 (continued).

\begin{tabular}{rrrr}
\hline & \multicolumn{3}{c}{ Diatom assemblages } \\
\cline { 2 - 4 } Depth & warm- & & \\
(mbsf) & water & neritic & upwelling \\
\hline & & & \\
\hline 20.00 & 3.66 & 17.07 & 34.55 \\
20.07 & 7.91 & 12.43 & 43.50 \\
20.15 & 6.30 & 21.85 & 27.73 \\
20.22 & 4.47 & 27.37 & 23.46 \\
20.30 & 1.64 & 25.25 & 23.93 \\
20.37 & 13.55 & 22.71 & 21.51 \\
20.45 & 5.38 & 19.89 & 44.09 \\
20.52 & 1.29 & 28.39 & 35.48 \\
20.60 & 5.12 & 37.80 & 22.05 \\
20.70 & 2.19 & 15.66 & 44.63 \\
20.77 & 6.57 & 18.25 & 43.07 \\
20.82 & 7.56 & 37.21 & 13.95 \\
20.90 & 3.05 & 43.29 & 29.27 \\
20.97 & 6.49 & 32.15 & 26.84 \\
21.05 & 2.42 & 17.58 & 43.94 \\
21.12 & 4.42 & 39.78 & 15.47 \\
21.20 & 14.77 & 32.58 & 9.47 \\
21.27 & 12.06 & 29.84 & 21.59 \\
21.35 & 10.61 & 43.94 & 7.58 \\
21.42 & 8.70 & 40.00 & 8.70 \\
21.50 & 11.59 & 31.16 & 7.97 \\
21.57 & 6.42 & 23.85 & 11.01 \\
21.65 & 2.25 & 44.94 & 3.37 \\
21.72 & 7.83 & 19.13 & 16.52 \\
21.80 & 1.14 & 25.14 & 12.00 \\
21.87 & 2.63 & 38.60 & 6.14 \\
21.82 & 11.06 & 19.91 & 7.08 \\
22.00 & 8.46 & 21.54 & 11.54 \\
22.10 & 10.11 & 26.97 & 12.36 \\
22.17 & 13.19 & 21.28 & 10.64 \\
22.25 & 13.20 & 12.18 & 10.66 \\
22.40 & 8.64 & 21.60 & 25.31 \\
22.55 & 2.94 & 29.41 & 27.94 \\
22.70 & 9.09 & 30.30 & 18.18 \\
22.77 & 9.26 & 25.93 & 7.41 \\
22.85 & 6.74 & 29.21 & 1.12 \\
22.92 & 9.09 & 25.45 & 18.18 \\
23.00 & 7.41 & 37.04 & 20.37 \\
23.07 & 1.61 & 11.29 & 27.42 \\
23.22 & 4.55 & 27.27 & 9.09 \\
\hline & & &
\end{tabular}


A

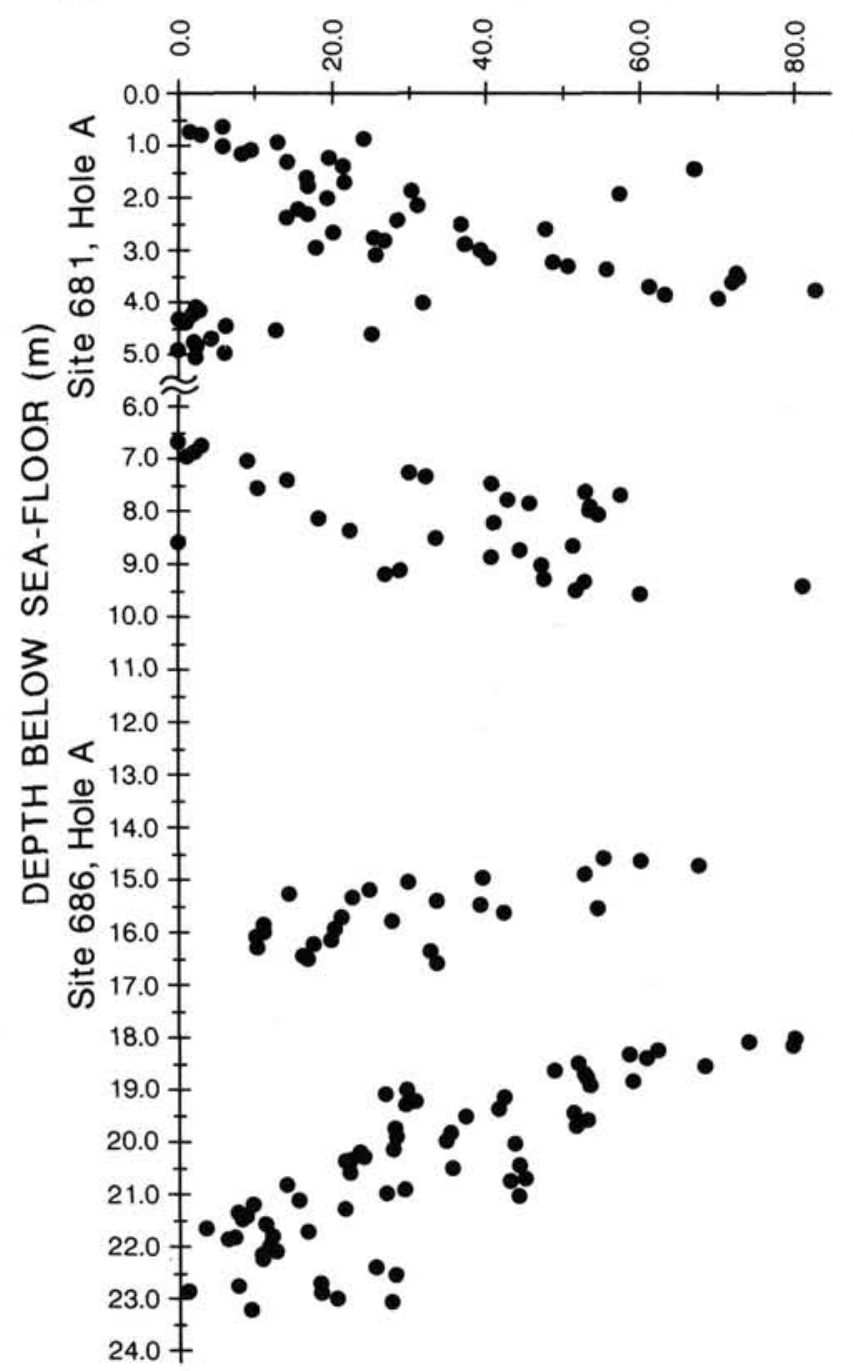

\section{B}

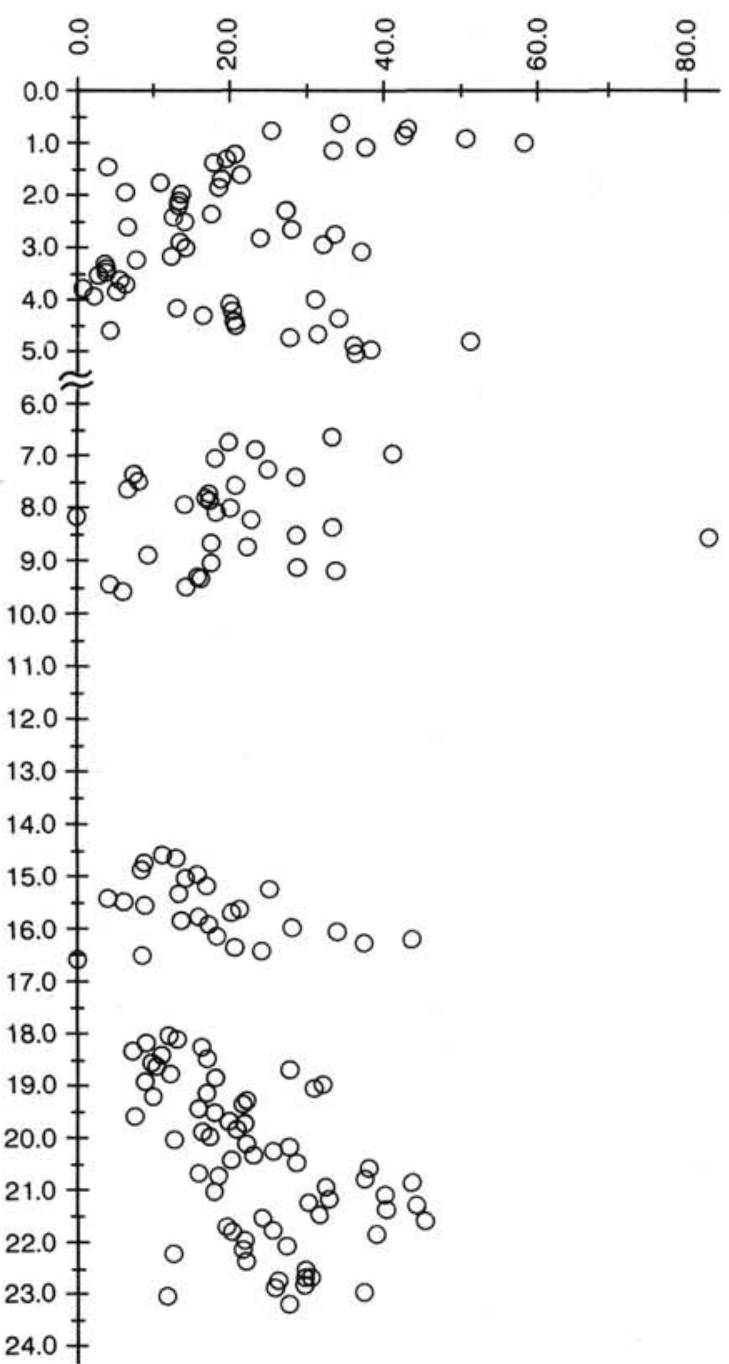

C \% WARM WATER SPECIES

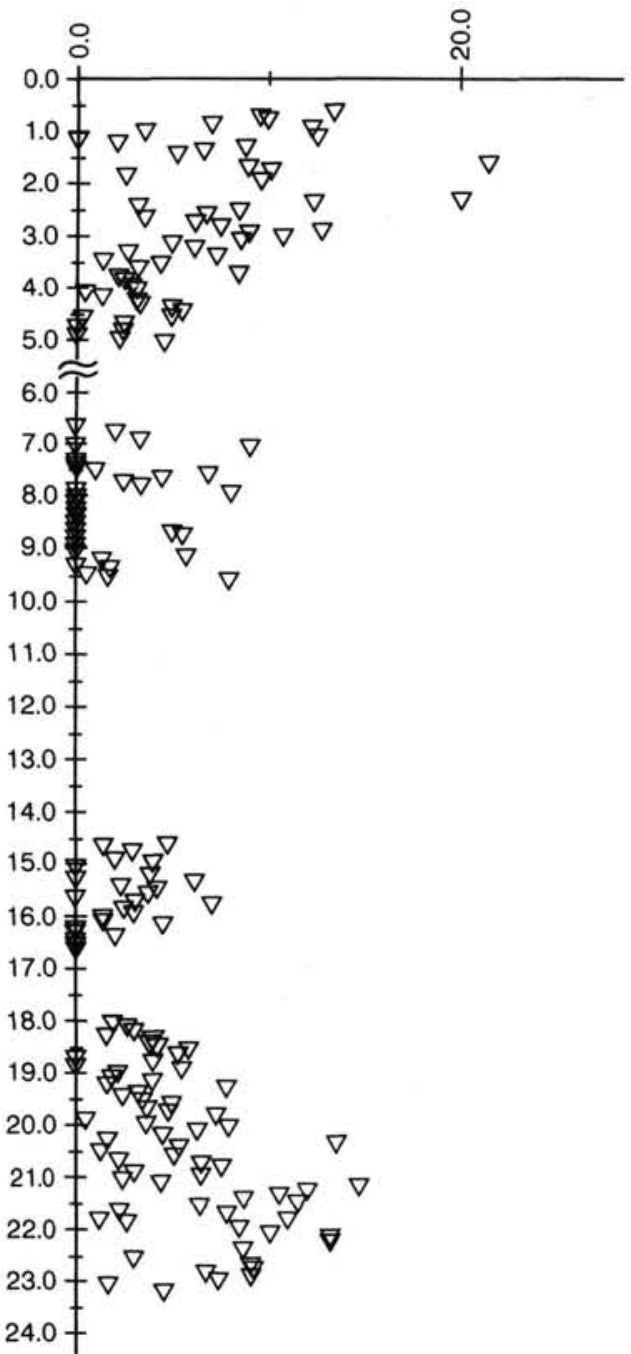

Figure 7. Percentage of upwelling species (A), neritic species (B) and warm water species (C) from Chaetoceros-free diatom assemblage at Holes $681 \mathrm{~A}$ and $686 \mathrm{~A}$. Note data between 0 to $5.08 \mathrm{mbsf}$ are from Hole $681 \mathrm{~A}$, and data from 6.6 to $23.22 \mathrm{mbsf}$ are from Hole $686 \mathrm{~A}$. 


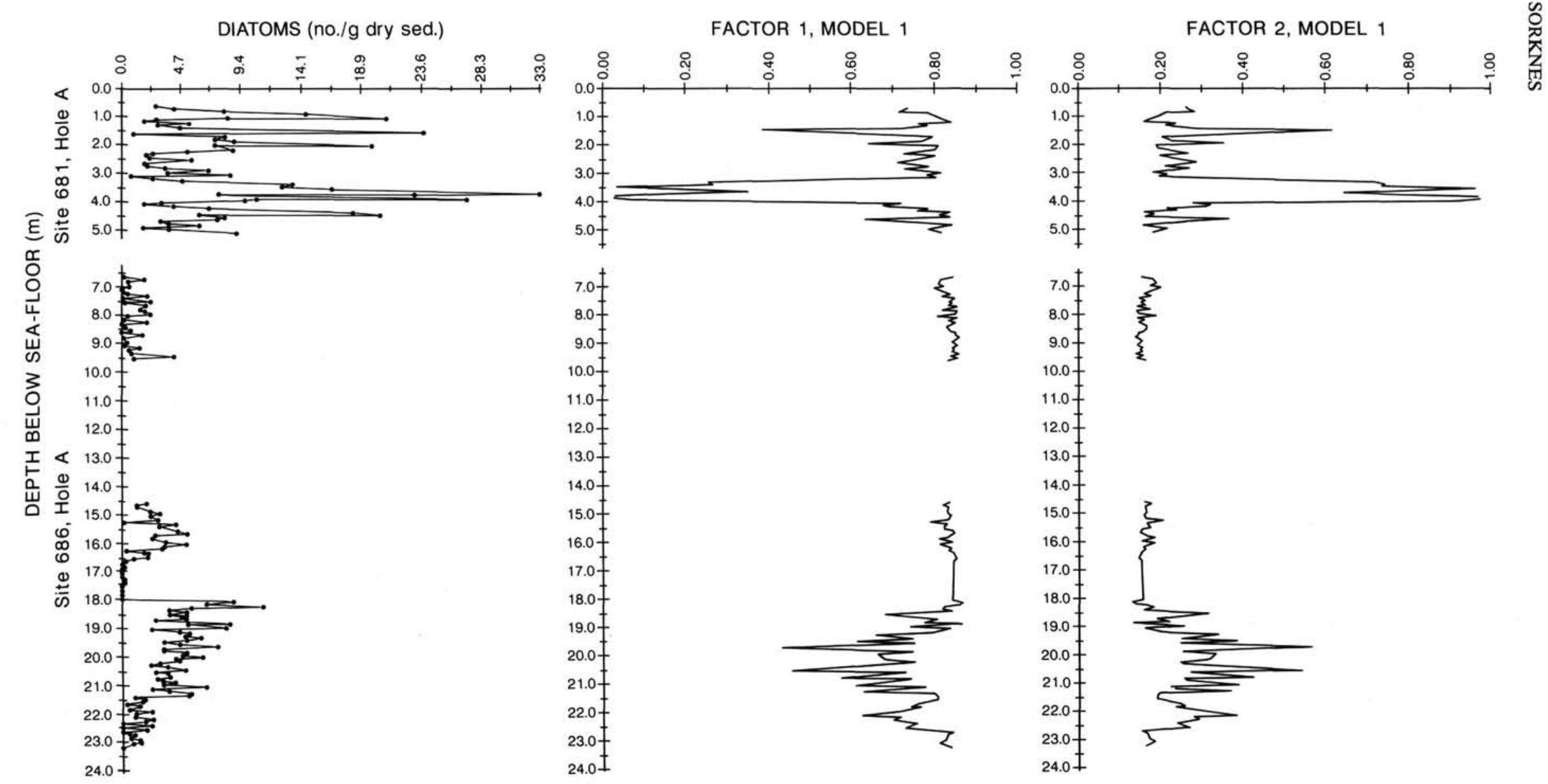

Figure 8. Factor 1 and 2 loadings of upwelling Model 1. Factor 1 is the Chaetoceros factor and Factor 2 is the Skeletonema costatum, Thalassionema nitzschioides factor. Note breaks in record due to insufficient diatom content and/or because of unsampled intervals. Diatom numbers in valves per gram dry sediment $\times 10^{6}$ are plotted at top of figure. 
Table 4. Normalized varimax matrix of Model 2 for samples from Holes 681A and 686A.

\begin{tabular}{|c|c|c|c|c|c|c|c|}
\hline $\begin{array}{l}\text { Normalized } \\
\text { Sample \# }\end{array}$ & $\begin{array}{l}\text { rarimax } \\
\text { Depth } \\
\text { (mbsf) }\end{array}$ & $\begin{array}{l}\text { ordinates } \\
\text { Comm. }\end{array}$ & 1 & 2 & 3 & 4 & 5 \\
\hline 1 & 0.66 & 0.8775 & 0.7869 & 0.0170 & 0.0676 & 0.0873 & 0.0411 \\
\hline 2 & 0.74 & 0.7216 & 0.8260 & 0.0108 & 0.0308 & 0.0651 & 0.0673 \\
\hline 3 & 0.81 & 0.9482 & 0.9561 & 0.0046 & 0.0339 & 0.0036 & -0.0018 \\
\hline 4 & 0.87 & 0.4884 & 0.1571 & 0.0064 & 0.6735 & 0.0156 & 0.1475 \\
\hline 5 & 0.95 & 0.3283 & 0.4886 & 0.0021 & 0.4039 & 0.0649 & 0.0404 \\
\hline 6 & 1.02 & 0.4094 & 0.8139 & 0.0030 & 0.1020 & 0.0611 & 0.0200 \\
\hline 7 & 1.10 & 0.8782 & 0.5789 & 0.0494 & 0.0096 & 0.2714 & 0.0907 \\
\hline 8 & 1.17 & 0.9628 & 0.7835 & 0.0248 & 0.0122 & 0.0893 & 0.0902 \\
\hline 9 & 1.24 & 0.9747 & 0.7732 & 0.0182 & 0.1487 & 0.0579 & 0.0021 \\
\hline 10 & 1.31 & 0.9848 & 0.7622 & 0.0184 & 0.1091 & 0.0642 & 0.0461 \\
\hline 11 & 1.39 & 0.9805 & 0.7146 & 0.0155 & 0.2104 & 0.0401 & 0.0194 \\
\hline 12 & 1.46 & 0.9908 & 0.0279 & 0.0013 & 0.9671 & 0.0036 & 0.0000 \\
\hline 13 & 1.63 & 0.9049 & 0.5256 & 0.0397 & 0.1886 & 0.2011 & 0.0451 \\
\hline 14 & 1.70 & 0.9529 & 0.7904 & 0.0209 & 0.1297 & 0.0569 & 0.0021 \\
\hline 15 & 1.78 & 0.9755 & 0.8756 & 0.0172 & 0.0783 & 0.0285 & -0.0003 \\
\hline 16 & 1.86 & 0.9815 & 0.4526 & 0.0108 & 0.4642 & 0.0645 & 0.0078 \\
\hline 17 & 1.93 & 0.9700 & 0.0131 & 0.0016 & 0.9784 & 0.0062 & 0.0007 \\
\hline 18 & 2.00 & 0.5192 & 0.5207 & 0.0053 & 0.4300 & 0.0419 & 0.0021 \\
\hline 19 & 2.15 & 0.5820 & 0.0865 & 0.0031 & 0.8821 & 0.0064 & 0.0218 \\
\hline 20 & 2.22 & 0.5886 & 0.6285 & 0.0040 & 0.3474 & 0.0200 & 0.0001 \\
\hline 21 & 2.30 & 0.8171 & 0.4004 & 0.0123 & 0.3993 & 0.1025 & 0.0855 \\
\hline 22 & 2.37 & 0.9614 & 0.6981 & 0.0292 & 0.1805 & 0.0387 & 0.0533 \\
\hline 23 & 2.44 & 0.9813 & 0.5971 & 0.0206 & 0.3482 & 0.0286 & 0.0055 \\
\hline 24 & 2.52 & 0.9786 & 0.3117 & 0.0060 & 0.6257 & 0.0535 & 0.0031 \\
\hline 25 & 2.60 & 0.9929 & 0.1542 & 0.0036 & 0.8358 & 0.0056 & 0.0008 \\
\hline 26 & 2.67 & 0.8716 & 0.6586 & 0.0047 & 0.3180 & 0.0187 & 0.0000 \\
\hline 27 & 2.75 & 0.8565 & 0.4656 & 0.0092 & 0.4255 & 0.0983 & 0.0013 \\
\hline 28 & 2.83 & 0.9833 & 0.5439 & 0.0088 & 0.3592 & 0.0857 & 0.0025 \\
\hline 29 & 2.90 & 0.9885 & 0.2143 & 0.0115 & 0.7141 & 0.0494 & 0.0106 \\
\hline 30 & 2.96 & 0.9281 & 0.4295 & 0.0168 & 0.1691 & 0.3188 & 0.0658 \\
\hline 31 & 3.03 & 0.9807 & 0.2283 & 0.0077 & 0.6896 & 0.0585 & 0.0159 \\
\hline 32 & 3.10 & 0.8820 & 0.5170 & 0.0110 & 0.3264 & 0.1330 & 0.0126 \\
\hline 33 & 3.18 & 0.9928 & 0.3536 & 0.0053 & 0.6238 & 0.0172 & 0.0001 \\
\hline 34 & 3.25 & 0.9916 & 0.2013 & 0.0038 & 0.7862 & 0.0086 & -0.0002 \\
\hline 35 & 3.32 & 0.9855 & 0.2543 & 0.0032 & 0.7398 & 0.0014 & -0.0013 \\
\hline 36 & 3.40 & 0.9872 & 0.1154 & 0.0030 & 0.8772 & 0.0044 & 0.0001 \\
\hline 37 & 3.48 & 0.9915 & 0.0117 & 0.0010 & 0.9847 & 0.0027 & 0.0000 \\
\hline 38 & 3.55 & 0.9920 & 0.0041 & 0.0016 & 0.9906 & 0.0019 & 0.0018 \\
\hline 39 & 3.63 & 0.9925 & 0.0078 & 0.0010 & 0.9861 & 0.0050 & 0.0001 \\
\hline 40 & 3.71 & 0.9901 & 0.0257 & 0.0016 & 0.9636 & 0.0089 & 0.0003 \\
\hline 41 & 3.79 & 0.9930 & 0.0000 & 0.0005 & 0.9989 & 0.0004 & 0.0001 \\
\hline 42 & 3.87 & 0.9912 & 0.0512 & 0.0019 & 0.9405 & 0.0065 & 0.0000 \\
\hline 43 & 3.94 & 0.9926 & 0.0199 & 0.0014 & 0.9773 & 0.0012 & 0.0003 \\
\hline 44 & 4.02 & 0.9326 & 0.1951 & 0.0060 & 0.7053 & 0.0636 & 0.0300 \\
\hline 45 & 4.09 & 0.9862 & 0.9593 & 0.0075 & 0.0176 & 0.0140 & -0.0016 \\
\hline 46 & 4.16 & 0.9751 & 0.9621 & 0.0090 & 0.0178 & 0.0098 & -0.0014 \\
\hline 47 & 4.23 & 0.9750 & 0.9162 & 0.0109 & 0.0219 & 0.0457 & 0.0053 \\
\hline 48 & 4.30 & 0.9741 & 0.9583 & 0.0080 & 0.0184 & 0.0152 & 0.0001 \\
\hline 49 & 4.38 & 0.9443 & 0.3741 & 0.0316 & 0.0058 & 0.2637 & 0.3248 \\
\hline 50 & 4.46 & 0.9740 & 0.7682 & 0.0220 & 0.0376 & 0.0797 & 0.0926 \\
\hline 51 & 4.53 & 0.9533 & 0.3570 & 0.0268 & 0.0306 & 0.3181 & 0.2676 \\
\hline 52 & 4.61 & 0.9714 & 0.9619 & 0.0139 & 0.0192 & 0.0004 & -0.0046 \\
\hline 53 & 4.68 & 0.9715 & 0.8245 & 0.0222 & 0.0133 & 0.1109 & 0.0291 \\
\hline 54 & 4.76 & 0.9657 & 0.8642 & 0.0152 & 0.0264 & 0.0703 & 0.0239 \\
\hline 55 & 4.83 & 0.9171 & 0.6378 & 0.0148 & 0.0094 & 0.2743 & 0.0637 \\
\hline 56 & 4.91 & 0.9607 & 0.7677 & 0.0169 & 0.0127 & 0.1247 & 0.0780 \\
\hline 57 & 4.98 & 0.8841 & 0.9361 & 0.0097 & 0.0220 & 0.0244 & 0.0078 \\
\hline 58 & 5.06 & 0.8905 & 0.9383 & 0.0063 & 0.0179 & 0.0359 & 0.0016 \\
\hline 59 & 6.67 & 0.1827 & 0.0011 & 0.0405 & -0.0024 & 0.8715 & 0.0844 \\
\hline 60 & 6.75 & 0.9365 & 0.1997 & 0.0443 & 0.0157 & 0.0459 & 0.6943 \\
\hline 61 & 6.90 & 0.9649 & 0.3077 & 0.0413 & 0.0151 & 0.0889 & 0.5469 \\
\hline 62 & 6.97 & 0.9469 & 0.0407 & 0.0298 & 0.0001 & 0.5332 & 0.3962 \\
\hline 63 & 7.05 & 0.9501 & 0.8071 & 0.0251 & 0.0146 & 0.0616 & 0.0916 \\
\hline 64 & 7.27 & 0.9652 & 0.0555 & 0.4416 & 0.0008 & 0.1063 & 0.3959 \\
\hline 65 & 7.35 & 0.9623 & 0.5650 & 0.4158 & 0.0105 & 0.0074 & 0.0013 \\
\hline 66 & 7.42 & 0.8256 & 0.0070 & 0.1433 & 0.0000 & 0.2686 & 0.5810 \\
\hline 67 & 7.50 & 0.9849 & 0.3369 & 0.6407 & 0.0135 & 0.0065 & 0.0025 \\
\hline 68 & 7.57 & 0.9611 & 0.0492 & 0.1216 & 0.0011 & 0.0457 & 0.7824 \\
\hline 69 & 7.65 & 0.9707 & 0.0939 & 0.8660 & 0.0294 & 0.0047 & -0.0059 \\
\hline 70 & 7.72 & 0.9752 & 0.0002 & 0.9791 & 0.0009 & 0.0078 & 0.0121 \\
\hline 71 & 7.80 & 0.9806 & 0.0075 & 0.5519 & 0.0883 & 0.0348 & 0.3174 \\
\hline 72 & 7.87 & 0.9448 & 0.0005 & 0.8735 & 0.0000 & 0.0519 & 0.0741 \\
\hline 73 & 7.95 & 0.9724 & 0.0076 & 0.9553 & 0.0023 & 0.0169 & 0.0178 \\
\hline 74 & 8.02 & 0.6666 & 0.1344 & 0.5791 & 0.1832 & 0.1033 & 0.0000 \\
\hline 75 & 8.10 & 0.8062 & 0.0047 & 0.6216 & -0.0001 & 0.0428 & 0.3308 \\
\hline
\end{tabular}


Table 4 (continued).

\begin{tabular}{|c|c|c|c|c|c|c|c|}
\hline $\begin{array}{l}\text { Normalize } \\
\text { Sample \# }\end{array}$ & $\begin{array}{l}\text { varimax } \\
\text { Depth } \\
\text { (mbsf) }\end{array}$ & ordinates & 1 & 2 & 3 & 4 & 5 \\
\hline 76 & 8.17 & 0.7340 & 0.4887 & 0.1751 & 0.0078 & -0.0043 & 0.3241 \\
\hline 77 & 8.25 & 0.9750 & 0.0750 & 0.7522 & 0.0008 & 0.0575 & 0.1145 \\
\hline 78 & 8.40 & 0.8208 & 0.8451 & 0.1119 & 0.0099 & 0.0294 & -0.0037 \\
\hline 79 & 8.55 & 0.9239 & 0.4535 & 0.3457 & 0.0056 & 0.1906 & 0.0046 \\
\hline 80 & 8.62 & 0.3459 & 0.0130 & 0.0370 & -0.0005 & 0.2599 & 0.6895 \\
\hline 81 & 8.70 & 0.9835 & 0.0078 & 0.9227 & 0.0032 & 0.0285 & 0.0378 \\
\hline 82 & 8.77 & 0.9601 & -0.0003 & 0.8604 & 0.0000 & 0.0452 & 0.0941 \\
\hline 83 & 8.92 & 0.7314 & 0.1698 & 0.7106 & 0.0006 & 0.0085 & 0.1104 \\
\hline 84 & 9.07 & 0.9178 & 0.0022 & 0.6877 & -0.0001 & 0.0536 & 0.2565 \\
\hline 85 & 9.15 & 0.9554 & 0.0818 & 0.6214 & 0.0062 & 0.1547 & 0.1358 \\
\hline 86 & 9.22 & 0.8435 & 0.0753 & 0.6484 & 0.0002 & 0.1242 & 0.1518 \\
\hline 87 & 9.30 & 0.9492 & 0.0042 & 0.7282 & 0.0506 & 0.0107 & 0.2064 \\
\hline 88 & 9.37 & 0.9914 & -0.0003 & 0.9255 & -0.0002 & 0.0225 & 0.0514 \\
\hline 89 & 9.45 & 0.9905 & 0.0011 & 1.0093 & 0.0144 & 0.0001 & -0.0249 \\
\hline 90 & 9.52 & 0.8658 & -0.0005 & 0.9714 & 0.0012 & 0.0234 & -0.0035 \\
\hline 91 & 9.60 & 0.9434 & 0.0477 & 0.9032 & 0.0416 & -0.0003 & 0.0071 \\
\hline 92 & 14.60 & 0.9238 & 0.0813 & 0.8535 & 0.0195 & 0.0126 & 0.0331 \\
\hline 93 & 14.67 & 0.5281 & 0.1348 & 0.5380 & 0.1076 & 0.0153 & 0.2042 \\
\hline 94 & 14.75 & 0.3859 & 0.2020 & 0.6649 & 0.0643 & 0.0027 & 0.0661 \\
\hline 95 & 14.90 & 0.5063 & 0.2218 & 0.4440 & 0.0250 & 0.0014 & 0.3078 \\
\hline 96 & 14.97 & 0.8774 & 0.2218 & 0.5719 & 0.0205 & 0.0507 & 0.1351 \\
\hline 97 & 15.05 & 0.8568 & 0.6088 & 0.2901 & 0.0072 & 0.0093 & 0.0846 \\
\hline 98 & 15.20 & 0.9266 & 0.3681 & 0.4882 & 0.0078 & 0.0691 & 0.0667 \\
\hline 99 & 15.27 & 0.8053 & 0.5947 & 0.0968 & 0.0062 & 0.0365 & 0.2659 \\
\hline 100 & 15.35 & 0.9353 & 0.6316 & 0.2272 & 0.0098 & 0.0041 & 0.1274 \\
\hline 101 & 15.42 & 0.9682 & 0.6390 & 0.3445 & 0.0138 & 0.0001 & 0.0026 \\
\hline 102 & 15.50 & 0.9897 & 0.4437 & 0.5452 & 0.0096 & 0.0015 & 0.0000 \\
\hline 103 & 15.57 & 0.9941 & 0.1045 & 0.8934 & 0.0037 & 0.0022 & -0.0038 \\
\hline 104 & 15.65 & 0.9315 & 0.0735 & 0.8576 & 0.0006 & 0.0673 & -0.0010 \\
\hline 105 & 15.72 & 0.9569 & 0.2266 & 0.4276 & 0.0070 & 0.1448 & 0.1941 \\
\hline 106 & 15.80 & 0.9764 & 0.5829 & 0.3781 & 0.0128 & 0.0205 & 0.0056 \\
\hline 107 & 15.87 & 0.9764 & 0.8981 & 0.0582 & 0.0153 & 0.0282 & 0.0002 \\
\hline 108 & 15.95 & 0.9458 & 0.4044 & 0.3854 & 0.0059 & 0.0130 & 0.1913 \\
\hline 109 & 16.03 & 0.9485 & 0.5537 & 0.0885 & 0.0521 & 0.0496 & 0.2561 \\
\hline 110 & 16.10 & 0.8789 & 0.4793 & 0.1281 & 0.0262 & 0.0818 & 0.2846 \\
\hline 111 & 16.17 & 0.9516 & 0.4863 & 0.3722 & 0.0173 & 0.0564 & 0.0678 \\
\hline 112 & 16.25 & 0.8905 & 0.1368 & 0.2237 & 0.0007 & 0.4556 & 0.1832 \\
\hline 113 & 16.32 & 0.9476 & 0.3630 & 0.1002 & 0.0040 & 0.2536 & 0.2793 \\
\hline 114 & 16.40 & 0.9785 & 0.0812 & 0.7340 & 0.0030 & 0.0840 & 0.0978 \\
\hline 115 & 16.47 & 0.9620 & 0.1200 & 0.2197 & 0.0015 & 0.1680 & 0.4908 \\
\hline 116 & 16.55 & 0.8915 & 0.0422 & 0.2611 & 0.0012 & 0.0027 & 0.6928 \\
\hline 117 & 16.62 & 0.8484 & 0.6150 & 0.3025 & 0.0088 & -0.0043 & 0.0693 \\
\hline 118 & 18.05 & 0.9793 & -0.0067 & 1.0032 & 0.0066 & 0.0074 & -0.0106 \\
\hline 119 & 18.12 & 0.9763 & -0.0004 & 0.9743 & 0.0017 & 0.0135 & -0.0102 \\
\hline 120 & 18.20 & 0.9793 & -0.0031 & 1.0101 & 0.0034 & 0.0025 & -0.0129 \\
\hline 121 & 18.27 & 0.9752 & 0.0023 & 0.9559 & 0.0042 & 0.0364 & -0.0013 \\
\hline 122 & 18.35 & 0.9846 & 0.0167 & 0.9656 & 0.0077 & 0.0085 & -0.0014 \\
\hline 123 & 18.42 & 0.9826 & 0.0032 & 0.9771 & 0.0069 & 0.0121 & 0.0007 \\
\hline 124 & 18.50 & 0.9835 & 0.0123 & 0.4344 & 0.4088 & 0.0737 & 0.0708 \\
\hline 125 & 18.57 & 0.9795 & -0.0122 & 0.7018 & 0.2849 & 0.0162 & 0.0093 \\
\hline 126 & 18.65 & 0.9774 & 0.0777 & 0.8257 & 0.0497 & 0.0159 & 0.0310 \\
\hline 127 & 18.72 & 0.9416 & 0.0020 & 0.7624 & 0.0630 & 0.1405 & 0.0320 \\
\hline 128 & 18.80 & 0.9832 & 0.0155 & 0.8098 & 0.1210 & 0.0381 & 0.0156 \\
\hline 129 & 18.87 & 0.9754 & 0.0002 & 0.9541 & 0.0000 & 0.0457 & 0.0000 \\
\hline 130 & 18.95 & 0.9684 & 0.0273 & 0.7736 & 0.1490 & 0.0168 & 0.0333 \\
\hline 131 & 19.02 & 0.8054 & 0.1284 & 0.4338 & 0.0066 & 0.4034 & 0.0279 \\
\hline 132 & 19.10 & 0.9009 & 0.1072 & 0.4932 & 0.0052 & 0.3646 & 0.0299 \\
\hline 133 & 19.17 & 0.9935 & 0.0553 & 0.5806 & 0.1321 & 0.0662 & 0.1658 \\
\hline 134 & 19.25 & 0.9356 & 0.1574 & 0.3541 & 0.1637 & 0.0151 & 0.3097 \\
\hline 135 & 19.32 & 0.9701 & 0.1440 & 0.2704 & 0.2052 & 0.2642 & 0.1162 \\
\hline 136 & 19.40 & 0.9779 & 0.0692 & 0.5614 & 0.1580 & 0.1115 & 0.1000 \\
\hline 137 & 19.47 & 0.9889 & 0.0434 & 0.4690 & 0.3808 & 0.0555 & 0.0513 \\
\hline 138 & 19.55 & 0.9441 & 0.0606 & 0.4842 & 0.2068 & 0.1585 & 0.0899 \\
\hline 139 & 19.62 & 0.9849 & 0.0277 & 0.2110 & 0.7089 & 0.0295 & 0.0228 \\
\hline 140 & 19.70 & 0.9800 & 0.0138 & 0.0943 & 0.7553 & 0.1024 & 0.0341 \\
\hline 141 & 19.77 & 0.9766 & 0.1790 & 0.1447 & 0.3139 & 0.1265 & 0.2358 \\
\hline 142 & 19.85 & 0.9858 & 0.1521 & 0.3381 & 0.2397 & 0.2267 & 0.0434 \\
\hline 143 & 19.92 & 0.9464 & 0.2329 & 0.3817 & 0.1000 & 0.1475 & 0.1379 \\
\hline 144 & 20.00 & 0.9694 & 0.1319 & 0.3269 & 0.2253 & 0.3147 & 0.0012 \\
\hline 145 & 20.07 & 0.9185 & 0.0187 & 0.2010 & 0.4727 & 0.2878 & -0.0198 \\
\hline 146 & 20.15 & 0.9542 & 0.1245 & 0.1981 & 0.1360 & 0.5296 & -0.0118 \\
\hline 147 & 20.22 & 0.9451 & 0.0734 & 0.1296 & 0.0845 & 0.7104 & -0.0020 \\
\hline 148 & 20.30 & 0.9604 & 0.0942 & 0.2101 & 0.1024 & 0.5880 & 0.0053 \\
\hline 149 & 20.37 & 0.9440 & 0.2111 & 0.1696 & 0.0856 & 0.5286 & -0.0051 \\
\hline 150 & 20.45 & 0.9725 & 0.0029 & 0.0411 & 0.6443 & 0.3116 & 0.0000 \\
\hline 151 & 20.52 & 0.9801 & 0.0019 & 0.0162 & 0.4609 & 0.5149 & 0.0061 \\
\hline
\end{tabular}


Table 4 (continued).

\begin{tabular}{|c|c|c|c|c|c|c|c|}
\hline $\begin{array}{l}\text { Normalize } \\
\text { Sample \# }\end{array}$ & $\begin{array}{l}\text { arimax c } \\
\text { Depth } \\
\text { (mbsf) }\end{array}$ & rdinates & 1 & 2 & 3 & 4 & 5 \\
\hline 152 & 20.60 & 0.9301 & 0.1481 & 0.1427 & 0.1011 & 0.4865 & 0.1216 \\
\hline 153 & 20.70 & 0.8268 & 0.0619 & 0.2675 & 0.5429 & 0.1263 & -0.0014 \\
\hline 154 & 20.77 & 0.9196 & -0.0162 & 0.0293 & 0.5964 & 0.3570 & -0.0010 \\
\hline 155 & 20.82 & 0.9803 & 0.0606 & 0.0141 & 0.0683 & 0.8543 & 0.0027 \\
\hline 156 & 20.90 & 0.9495 & -0.0009 & 0.0975 & 0.1206 & 0.7584 & 0.0226 \\
\hline 157 & 20.97 & 0.9710 & 0.0673 & 0.0867 & 0.2270 & 0.6002 & 0.0188 \\
\hline 158 & 21.05 & 0.9889 & 0.0038 & 0.1234 & 0.6376 & 0.1660 & 0.0693 \\
\hline 159 & 21.12 & 0.9172 & -0.0004 & 0.0458 & 0.0479 & 0.8906 & 0.0153 \\
\hline 160 & 21.20 & 0.9524 & 0.1183 & 0.0318 & 0.0402 & 0.7777 & 0.0320 \\
\hline 161 & 21.27 & 0.9673 & 0.1090 & 0.0199 & 0.2697 & 0.5525 & 0.0489 \\
\hline 162 & 21.35 & 0.9579 & 0.0821 & 0.0092 & 0.0332 & 0.8197 & 0.0559 \\
\hline 163 & 21.42 & 0.9743 & 0.1780 & 0.0125 & 0.0375 & 0.7129 & 0.0591 \\
\hline 164 & 21.50 & 0.9727 & 0.2038 & 0.0134 & 0.0528 & 0.6772 & 0.0528 \\
\hline 165 & 21.57 & 0.9565 & 0.3227 & 0.0165 & 0.1210 & 0.4795 & 0.0603 \\
\hline 166 & 21.65 & 0.9642 & 0.2233 & 0.0162 & 0.0141 & 0.6274 & 0.1190 \\
\hline 167 & 21.72 & 0.9635 & 0.3526 & 0.0283 & 0.2197 & 0.1990 & 0.2004 \\
\hline 168 & 21.80 & 0.9828 & 0.3539 & 0.0322 & 0.0955 & 0.2586 & 0.2598 \\
\hline 169 & 21.87 & 0.9769 & 0.2034 & 0.0232 & 0.0277 & 0.5231 & 0.2226 \\
\hline 170 & 21.82 & 0.9547 & 0.5281 & 0.0302 & 0.0699 & 0.2083 & 0.1635 \\
\hline 171 & 22.00 & 0.9714 & 0.3859 & 0.0402 & 0.1017 & 0.1541 & 0.3181 \\
\hline 172 & 22.10 & 0.9665 & 0.3739 & 0.0265 & 0.1374 & 0.2428 & 0.2195 \\
\hline 173 & 22.17 & 0.9443 & 0.5369 & 0.0303 & 0.1108 & 0.1326 & 0.1895 \\
\hline 174 & 22.25 & 0.9001 & 0.4134 & 0.0419 & 0.1104 & 0.0381 & 0.3961 \\
\hline 175 & 22.40 & 0.9728 & 0.1730 & 0.0772 & 0.3076 & 0.2216 & 0.2206 \\
\hline 176 & 22.55 & 0.9674 & 0.0583 & 0.0242 & 0.3539 & 0.2307 & 0.3329 \\
\hline 177 & 22.70 & 0.9678 & 0.0122 & 0.2236 & 0.0000 & 0.7625 & -0.0018 \\
\hline 178 & 22.77 & 0.7113 & 0.0334 & 0.0228 & 0.0117 & 0.9264 & -0.0057 \\
\hline 179 & 22.85 & 0.8037 & 0.0731 & 0.0262 & 0.0008 & 0.7656 & 0.1344 \\
\hline 180 & 22.92 & 0.8517 & 0.0090 & 0.1405 & 0.0385 & 0.7713 & 0.0407 \\
\hline 181 & 23.00 & 0.9451 & 0.0280 & 0.0755 & 0.0381 & 0.7264 & 0.1320 \\
\hline 182 & 23.07 & 0.6839 & 0.0919 & 0.2675 & 0.0436 & 0.5736 & -0.0234 \\
\hline 183 & 23.22 & 0.8807 & 0.0622 & 0.0575 & 0.0004 & 0.8664 & -0.0135 \\
\hline \multicolumn{8}{|c|}{ Varimax end-member composition matrix } \\
\hline & Var. & & 1 & 2 & 3 & 4 & 5 \\
\hline \multicolumn{3}{|c|}{$\begin{array}{l}\text { Thalassionema nitzschioides } \\
\text { var. parva }\end{array}$} & 0.001 & 0.010 & 0.022 & 0.097 & -0.003 \\
\hline \multicolumn{3}{|c|}{ Thalassionema nitzschioides } & 0.963 & 0.062 & 0.133 & 0.006 & -0.127 \\
\hline \multicolumn{3}{|c|}{ Thalassiosira eccentrica } & 0.065 & 0.182 & 0.024 & -0.080 & 0.887 \\
\hline \multicolumn{3}{|c|}{ Thalassiosira leptopus } & -0.073 & -0.012 & -0.015 & 0.552 & -0.237 \\
\hline \multicolumn{3}{|c|}{ Thalassiosira oestrupii } & -0.002 & 0.017 & -0.007 & 0.039 & 0.021 \\
\hline \multicolumn{3}{|c|}{ Thalassiosira sp. \#1 } & -0.019 & 0.062 & -0.015 & 0.103 & 0.000 \\
\hline \multicolumn{3}{|c|}{ Coscinodiscus radiatus } & 0.045 & 0.036 & -0.008 & 0.012 & 0.147 \\
\hline \multicolumn{3}{|c|}{ Coscinodiscus asteromphalus } & 0.007 & 0.015 & -0.012 & 0.025 & 0.056 \\
\hline \multicolumn{3}{|c|}{ Delphineis karstenii } & -0.085 & 0.967 & -0.014 & -0.029 & -0.200 \\
\hline \multicolumn{3}{|c|}{ Skeletonema costatum } & -0.136 & 0.009 & 0.987 & 0.018 & -0.001 \\
\hline \multicolumn{3}{|c|}{ Rhizosolenia bergonii } & 0.020 & -0.004 & 0.030 & 0.030 & 0.005 \\
\hline \multicolumn{3}{|c|}{ Actinoptychus sp. (undulatus) } & 0.063 & 0.060 & -0.011 & 0.810 & 0.248 \\
\hline \multicolumn{3}{|c|}{ Pseudoeunotia doliolus } & 0.035 & 0.009 & 0.009 & 0.023 & -0.009 \\
\hline \multicolumn{3}{|c|}{ Actinocyclus ehrenbergii } & 0.036 & 0.027 & -0.026 & 0.014 & 0.044 \\
\hline \multicolumn{3}{|c|}{ Thalassiothrix longissima } & 0.039 & 0.010 & -0.004 & -0.002 & 0.007 \\
\hline \multicolumn{3}{|c|}{ Ditylum brightwellii } & 0.093 & 0.125 & -0.021 & -0.086 & 0.106 \\
\hline \multicolumn{3}{|c|}{ Cyclotella $\mathrm{sp}$. striata/stylorum) } & 0.132 & -0.042 & 0.031 & -0.021 & -0.024 \\
\hline Coscinodis & is nodulif & & 0.032 & -0.018 & 0.062 & -0.022 & -0.006 \\
\hline
\end{tabular}

Samples 1 through 58 are from Hole 681A, and samples 59 through 183 are from Hole 686A. Varimax end-member composition matrix is at the end of this table.

Strongest upwelling influence seem to have occurred during interglacial stages, whereas weaker upwelling occurred during glacials.

Typical upwelling diatoms are small and thinly silicified and thus prone to dissolution and fragmentation. Their sediment record can only be preserved under certain circumstances, such as when the coastal upwelling phenomenon is strong and persistent and when bottom-current velocities are minimal. Because Hole $681 \mathrm{~A}$ is nearer to a presently active upwelling center it should show a stronger signal of coastal upwelling today. In contrast, Hole $686 \mathrm{~A}$ is slightly north of a presently active upwelling plume and should have received lower upwelling signals. When comparing the downhole upwelling distributions at the two sites, these trends hold true.
During the latest Quaternary, Hole 681A received higher upwelling contributions than Hole 686A.

Diatoms retrieved from the coarse fraction can be used only with great caution as indicators of increased diatom and, thus, primary production. Therefore, our data cannot be directly compared with those presented by Oberhaensli et al. (this volume). In general, during intervals of increased warm-water influx and increased neritic conditions, higher contributions of larger diatoms will be present in the samples.

Assuming that Wefer et al.'s oxygen-isotope stage assignments (this volume) and our age interpretation is correct and that the correlation of predominantly laminated sedimentary intervals with interglacial periods and intervals with biotur- 


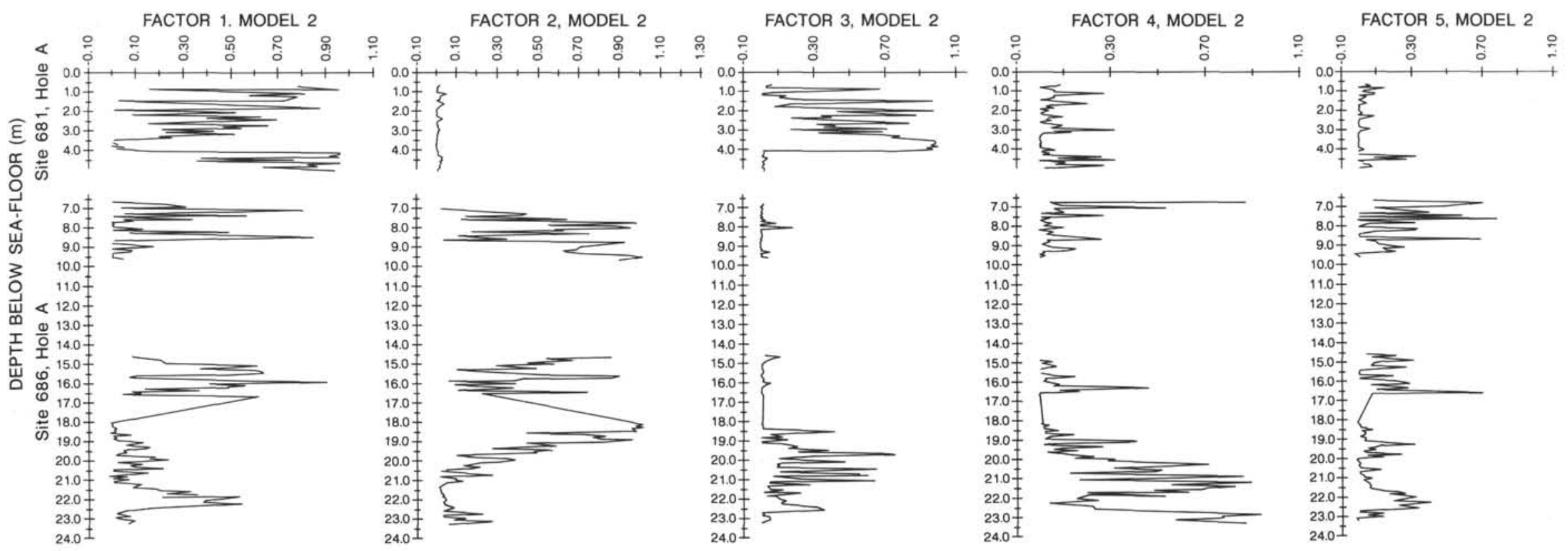

Figure 9. Factors 1 through 5 loading of upwelling Model 2 with Chaetoceros and some other species removed from database. Factor 1 consists of Thalassionema nitzschioides, Factor 2 of Delphineis karstenii, Factor 3 of Skeletonema costatum, Factor 4 of Actinoptychus and Thalassiosira leptopus, and Factor 5 of Thalassiosira eccentrica. Note breaks in record due to insufficient diatom content and/or because of intervals not sampled. See Table 4 for factor definitions and loadings. 


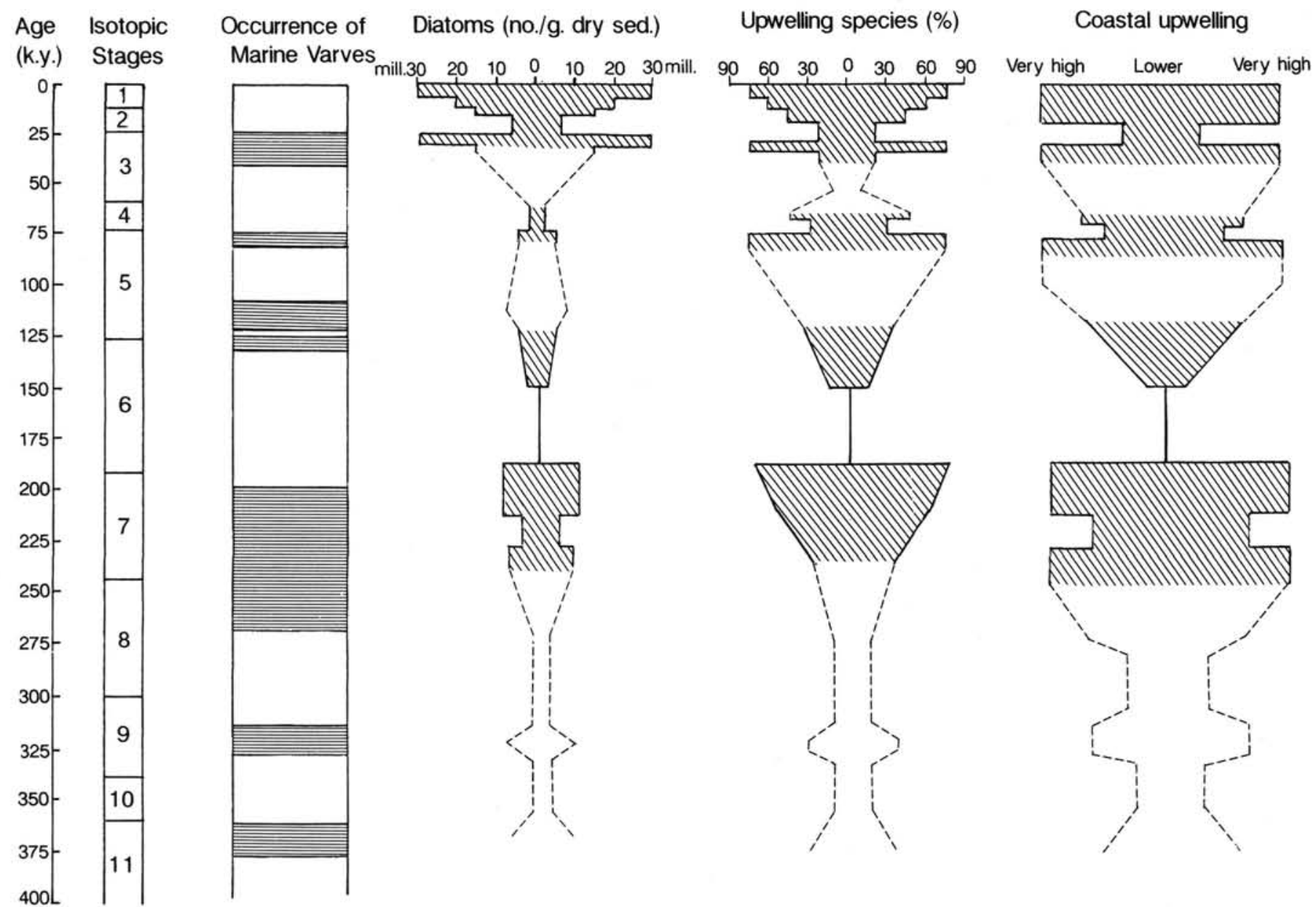

Figure 10. Model of upwelling variability at Holes $681 \mathrm{~A}$ and $686 \mathrm{~A}$, based on correlation among Holes $680 \mathrm{~B}, 681 \mathrm{~A}$, and $686 \mathrm{~A}$.

bated/laminated intervals with glacials is correct, then the following conclusions (summarized in Fig. 10) can be drawn from both sites: The upwelling phenomenon along the Peruvian continental margin is a stable event in space and time. Increased productivity and increased opal export occurs during interglacial events. This increased biogenic flux causes bottom waters to become increasingly anoxic owing to the increased amount of oxidizable organic matter. We think that our data indicate at least a two-fold increase of productivity along the Peruvian margin in general. Because the same signals seem to co-occur at both sites, the controlling factors for increased productivity must be seen as a general increase in wind velocities triggering through Ekman transport deeper, nutrient-rich water being upwelled.

Comparing our data with results presented by Farrimond et al. (this volume) we notice apparent discrepancies. We assume that our correlation between Holes 686A and 686B (Schrader and Sorknes, unpubl. data) is correct in placing similar sedimentary units at similar depth. The $U_{37}^{k}$ index (Farrimond et al., this volume) indicates higher surface-water temperatures occurred during the finely laminated interval at 20 mbsf; we do find, on the other hand, a substantial increase in the diatom-upwelling assemblage. This increase in upwelling floras should show lower temperatures because of the upwelling effect, contributing deeper waters that are colder and richer in nutrients to the surface. The $U_{37}^{k}$ curve corresponds well with our curves that show the same general trends.

\section{CONCLUSIONS}

Marine planktonic diatoms are abundant and well preserved in most samples studied. Laminated-varved intervals have more diatoms than bioturbated/homogeneous intervals. Preservation of diatom frustules is good, but fragmentation of frustules seems to increase in the bioturbated intervals. Frustules are more fragmented at the shallower Site 681 , compared with the deeper Site 686 .

Diatom species successions and associations allow classification of upwelling phenomena in (1) strong upwelling, (2) intermittent upwelling, (3) weak upwelling, and (4) no upwelling. Upwelling was present over the total time period studied $(400,000 \mathrm{yr})$, with increased strong upwelling conditions during deposition of the laminated-varved sediment facies.

Warm-water admixtures occurred during oxygen-isotope Stages 2, 4, 6. Upwelling noticeably increased during oxygenisotope Stages 3, 5, 7. Variations in upwelling intensities may have been constant in time and space, controlling deposition of sedimentary structures and components over wide areas on the shelf and slope.

\section{ACKNOWLEDGMENTS}

Tim Schrader (Tulane Univ., New Orleans) ported the mainframe computer programs to our PC environment. Nick Pisias, Alan Mix (both at College of Oceanography, Oregon State Univ., Corvallis), and Bill Full (Univ. of South Carolina) made source codes available of their Fortran CABFAC and VPLOT programs. Rainer Gersonde shared his 
new preparation technique for quantitative diatom mounts with us. Gerold Wefer, Hedi Oberhaensli, Peter Heinze, and R. Schneider (all Geol. Inst. Univ. of Bremen) and E. Suess (Geomar, Kiel) made their publications available to us. This paper was reviewed by A. K. Lycke, J. Barron, and J. Parrish. Norges allmennvitenskapelige forskningsrad (NAVF) funded this research through Grant Schr. D.41.31.150.

\section{REFERENCES}

Baumgartner, T., Ferreira-Bartrina, V., Schrader, H., and Soutar, A., 1985. A 20-year varve record of siliceous phytoplankton variability in the Central Gulf of California. Mar. Geol., 64:113129.

Colinvaux, P., 1972. Climate and the Galapagos Islands. Nature, 240:17-20.

De Mendiola, B. R., 1980. Variations of phytoplankton along the Peruvian coast. International Decade of Ocean Exploration (IDOE), Int. Symp. Coastal Upwelling, Los Angeles (Abstract).

DeVries, T. J., 1979. Nekton remains, diatoms, and Holocene upwelling off Peru [M.S. thesis]. Oregon State Univ., School of Oceanography, Corvallis, Oregon.

DeVries, T. J., and Pearcy, W. G., 1982. Fish debris in sediments of the upwelling zone off central Peru: a late Quaternary record. Deep Sea Res., 28:87-109.

DeVries, T., and Schrader, H., 1981. Variation of upwelling/oceanic conditions during the latest Pleistocene through Holocene off the Peruvian coast: A diatom record. Mar. Micropaleontol., 6:157-167.

Diester-Haass, L. 1978. Sediments as indicators of upwelling. In Boje, R., and Tomczak, M. (Eds.), Upwelling Ecosystems: BerlinHeidelberg-New York (Springer-Verlag), 261-281.

Ehrlich, R., and Full, W. E., 1987. Sorting out geology-unmixing mixtures. In Size, W. B. (Ed.), Use and Abuse of Statistical Methods in the Earth Sciences:, New York-Oxford (Oxford Univ. Press), 33-46.

Haq, B. U., Hardenbol, J., and Vail, P. R., 1987. Chronology of fluctuating sea levels since the Triassic ( 250 million years ago to present). Science, 235:1150-1167.

Hussong, D. M., Dang, S. P., Kulm, L. D. Couch, R. W., and Hilde, T.W.C. (Eds.), 1985. Atlas of the Ocean Drilling Program, Regional Atlas Series 9, Peru-Chile Trench off Peru: Woods Hole, MA (Mar. Sci. Int.).

Imbrie, J.,Hays, J. D., Martinson, D. G., McIntyre, A., Mix, A. C., Morley, J. J., Pisias, N. G., Prell, W., and Shackleton, N. J., 1984. The orbital theory of Pleistocene climate: support from a revised chronology of the marine ${ }^{18} \mathrm{O}$ record. In Berger, A. et al. (Eds.), Milankovitch and Climate: Dordrecht (D. Reidel).

Jones, B. H., Brink, K. H., Dugdale, R. C., Stuart, D. W., van Leer, J. C., Blasco, D., and Kelly, J. C., 1983. Observations of a persistent upwelling center off Point Conception, California. In Suess, E., and Thiede, J. (Eds.), Coastal Upwelling: Its Sediment Record: New York (Plenum Press), 37-60.

Klovan, J. E., and Imbrie, J., 1971. An algorithm and Fortran IV program for large scale Q-mode factor analysis. J. Int. Assoc. Mathematical Geol., 3:61-76.

Molina-Cruz, A., 1977. The relationship of the southern trade winds to upwelling processes during the last 75,000 years. Quat. Res., $8: 324-338$

Prell, W., Imbrie, J., Martinson, D. G., Morley, J.J., Pisias, N. G., Shackleton, N. J., and Streeter, H. F., 1986. Graphic correlation of oxygen isotope stratigraphy application to the late Quaternary. Paleoceanography, 1:137-162.

Quinn, W., 1971. Late Quaternary meteorology and oceanographic development in the equatorial Pacific. Nature, 229:330-331.

Richert, P., 1975. Die raeumliche Verteilung und zeitliche Entwicklung des Phytoplanktons mit besonderer Beruecksichtigung der Diatomeen im N.W.-Afrikanischen Auftriebswassergebiet [Ph. D. dissert.]. Univ. of Kiel, West Germany.

1976. Relationship between diatom biocoenoses and taphocoenoses in upwelling areas off West Africa. In Proc. 4th Symp. on Recent and Fossil Mar. Diatoms, Oslo, 1976 (Abstract).

Schrader, H., 1987. Marine varved sediments. 1987 Yearbook of Science and Technology: New York (McGraw Hill).

Schrader, H., and Gersonde, R. 1978. Diatoms and silicoflagellates. In Zachariasse, W. J., Riedel, W. R., Sanfilippo, A., Schmidt, R. R., et al. (Eds.), Micropaleontological counting methods and techniques-an exercise on an 8-m section of the lower Pliocene of Capo Rossello, Sicily. Utrecht Micropaleontol. Bull., 17:129-176.

Schrader, H., and Schuette, G., 1981.Marine diatoms. In Emiliani, C. (Ed.), The Oceanic Lithosphere: New York (John Wiley), 1179 1232.

Schuette, G., and Schrader, H., 1979a. Diatom taphocoenoses in the coastal upwelling area off western South America. Nova Hedwigia, Beih., 64:359-378.

1979b. Diatom taphocoenoses in the coastal upwelling areas off Western South America. School of Oceanography, Reference 79-8, Data Report 73: Corvallis, OR (Oregon Sate Univ.).

1981a. Diatoms in surface sediments: A reflection of coastal upwelling. In Richards, F. A. (Ed.), Coastal Upwelling: Washington (Am. Geophys. Uni.), 372-380.

, 1981b. Diatom taphocoenoses in the coastal upwelling area off Southwest Africa. Mar. Micropaleontol., 6:131-155.

Semina, H. J., 1971. Distribution of plankton in the South Eastern Pacific. Trans. Inst. Oceanol., USSR, 89:43-59.

Shipboard Scientific Party, 1988. Site . In Suess, E., von Huene, R. et al., Proc. ODP, Init. Repts., 112: College Station, TX (Ocean Drilling Program).

Sukhanova, I. N., Konovalova, G. V., and Ratkova, T. N., 1978. Phytoplankton numbers and species structure in the Peruvian upwelling region. Oceanology, 18:72-76.

Soutar, A., Johnson, S. R., and Baumgartner, T. R., 1982. In search of modern depositional analogs to the Monterey Formation. In Garrison, G. E., and Douglas, R. G. (Eds.), The Monterey Formation and Related Siliceous Rocks of California: Tulsa (Soc. Econ. Paleontol. Mineral.), 123-147.

Suess, E., von Huene, R. et al., 1988. Proc. ODP, Init. Repts., 112: College Station, TX (Ocean Drilling Program).

Zuta, S., and Guillen, O., 1970. Oceanografia de las aguas costeras del Peru. Inst. Mar. Peru, Bol., 2:161-323.

Zuta, S., Rivera, T., and Bustamante, A., 1978. Hydrologic aspects of the main upwelling areas off Peru. In Boje, R., and Tomczak, M. (Eds.), Upwelling Ecosystems: Berlin-Heidelberg-New York (Springer-Verlag), 235-260.

Date of initial receipt: 28 November 1988

Date of acceptance: 26 May 1989

Ms 112B-188 